\title{
Recent trends in metals extraction ${ }^{(\bullet)}$
}

\author{
M. Regel-Rosocka* and F. J. Alguacil**
}

\begin{abstract}
After near 70 years of practical usage, solvent extraction is a perfectly mastered technique of separation, widely used on an industrial scale for the separation of metals mainly from raw materials. However, currently, in the era of depleting natural resources and increasingly less accessible deposits, environmental restrictions, etc., an increasing interest, both from social and economical constrains, is being directed at the extraction of metals from the secondary sources (such as batteries, electronic scrap). In many cases, solvent extraction, due to its operational characteristics, can be considered as the Best Available Technology for the purpose of separating multielemental metal solutions. This paper provides a brief overview of past achievements and present scenario of solvent extraction investigations and developments, describing some recently commissioned solvent extraction plants, whereas the Skorpion Zinc plant (Namibia) for zinc extraction from raw materials and caesium removal from radioactive High Level Wastes (HLWs) are told over in detail as case studies. The paper also presents some proposals for the use of liquid-liquid extraction to separate metal ions from secondary sources (e.g. cobalt from industrial waste streams). The review highlights the emerging use of ionic liquids as new extractants for metals, providing an insight into this exciting research field. Despite its detractors, solvent extraction has entered in force into XXI century as a leading separation technology for metals.
\end{abstract}

Keywords

Liquid-liquid extraction; Metals; Extractants; Ionic liquids; Caesium.

\section{Tendencias recientes en la extracción de metales}

Resumen

\begin{abstract}
Después de casi 70 años de uso práctico, la extracción líquido-líquido o extracción con disolventes es una técnica de separación muy evolucionada, utilizándose a escala industrial en el beneficio de metales obtenidos de diversas materias primas. Sin embargo, con el agotamiento de los recursos naturales y el aumento de depósitos minerales de más difícil acceso, restricciones medio ambientales, etc., ha aumentado el interés, tanto desde el punto de vista económico como social, en la recuperación de los metales contenidos en materiales secundarios (baterías, chatarras electrónicas). En muchos casos, la extracción líquido-líquido y debido a sus características operacionales, se considera como la mejor tecnología disponible respecto a la separación de disoluciones metálicas multielementales. Este trabajo considera algunos de estos anteriores estudios y presenta la situación actual de la tecnología en cuanto a investigaciones y desarrollos, describiendo algunas de las más recientes plantas industriales en funcionamiento, detallando la planta Skorpion (Namibia) para la obtención de zinc, así como investigaciones encaminadas a la eliminación de cesio de efluentes radioactivos. También se presentan algunas de las propuestas encaminadas a la separación-recuperación de metales de materiales secundarios (por ejemplo, cobalto). Por último, se describe el uso emergente de los iones líquidos como agentes de extracción de los metales como una forma de introducción a este fascinante campo de aplicación de la tecnología y de estos compuestos. A pesar de sus detractores, la extracción líquido-líquido se posiciona en estos primeros años del siglo XXI como la tecnología líder en la separación de metales.
\end{abstract}

Palabras clave Extracción líquido-liquido; Metales; Agentes de extracción; Líquidos iónicos; Cesio.

\section{INTRODUCTION}

Application of liquid-liquid extraction in metallurgical processes dates back to the $40 \mathrm{~s}$ of the $20^{\text {th }}$ century and in the beginning concerned particularly uranium. A rapid development of the extraction plants located directly at the source of raw materials (at mines) took place in $50 \mathrm{~s}$ and $60 \mathrm{~s}$. A success of the first installations used for the uranium extraction resulted in construction of extraction plant for copper separation in $1969^{[1]}$. This opened the way for the application of this separation technique in

(•) Trabajo recibido el día 16 de mayo de 2013 y aceptado en su forma final el día 19 de julio de 2013.

* Institute of Chemical Technology and Engineering, Poznan Universtity of Technology, PI. M. Skłodowskiej-Curie 2, 60-965 Poznan. Poland, E-mail: magdalena.regel-rosocka@put.poznan.pl.

** Centro Nacional de Investigaciones Metalurgicas (CENIM-CSIC), Avda. Gregorio del Amo 8, 28040 Madrid. Spain, E-mail: fjalgua@cenim.csic.es. 
hydrometallurgy of many metals resulting in research on mechanisms of extraction reactions, the development of new extractants and new equipment for effective mass exchange during extraction.

\section{METAL ION EXTRACTION}

Liquid-liquid extraction, also called solvent extraction (SX), is a well-known separation technique, widely used for separation of such metal ions as alkali metals (rubidium,cesium), alkaline earth metals (magnesium, calcium), transition (cobalt, nickel, zinc, copper), rare (niobium, tantalum, molybdenum), noble (palladium, platinum, gold), actinides (uranium, actinium) and the lanthanides from aqueous solutions ${ }^{[1]}$. The required metals are separated not only from sulphate solutions, but also from chloride or mixed chloride/ammonium solutions. Prior to selection of appropriate extractant a number of parameters of the separated system must be taken into consideration, i.e. $\mathrm{pH}$, accompanying metals, concentration, ionic strength, presence of complexing anions. Afterwards selection can be made from a great variety of organic compounds divided according to their chemical nature into the following extractants: the commonly used acidic-non-chelating organophosphorous acids (bis(2-ethylhexyl) phosphoric acid-DEHPA, bis (2,4,4-trimethylpentyl) phosphinic acid-Cyanex 272, 2-ethylhexylphosphonic acid 2-ethylhexyl monoester - PC 88A and bis $(2,4,4$ trimethylpentyl) monothiophosphinic acid-Cyanex 302; chelating hydroxyoximes (e.g. mixture of LIX 64N + LIX 860) and $\beta$-diketones (e.g. LIX 54), ketoximes (LIX-84-IC), solvating extractants (tributyl phosphate-TBP, trialkylphosphine oxides-Cyanex 923), basic extractants (alkylamines-Alamine 336, Primene 81R, Primene TOA, Amberlite LA2, quaternary ammonium salt: trialkyl (C8:C10 = 2:1) methylammonium

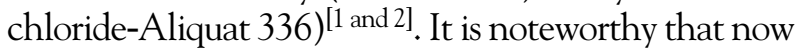
Aliquat 336, known in SX processes form the fifties of the XX century, is classified also as an ionic liquid ${ }^{[3]}$. The extractants that are often used nowadays in SX are presented in table I.

Table I. Structures, commercial names and active substances of the frequently used extractants

Tabla I. Estructura, nombre comercial y grupos activos de agentes de extracción de uso frecuente

\begin{tabular}{lll}
\hline Class of extractant & \multicolumn{1}{c}{ Name } \\
\hline Acidic & $\begin{array}{l}\text { DEHPA } \\
\text { (bis(2-ethylhexyl) phosphoric acid) }\end{array}$ & $\begin{array}{l}\text { Cyanex 272 (bis(2,4, } \\
\text { 4-trimethylpentyl) phosphinic acid) }\end{array}$ \\
\hline Chelating & $\begin{array}{l}\text { Cyanex 301 (bis(2,4, } \\
\text { 4-trimethylpentyl) dithiophosphinic } \\
\text { acid) }\end{array}$ \\
\hline
\end{tabular}


Table I. Continuation

Tabla I. Continuación

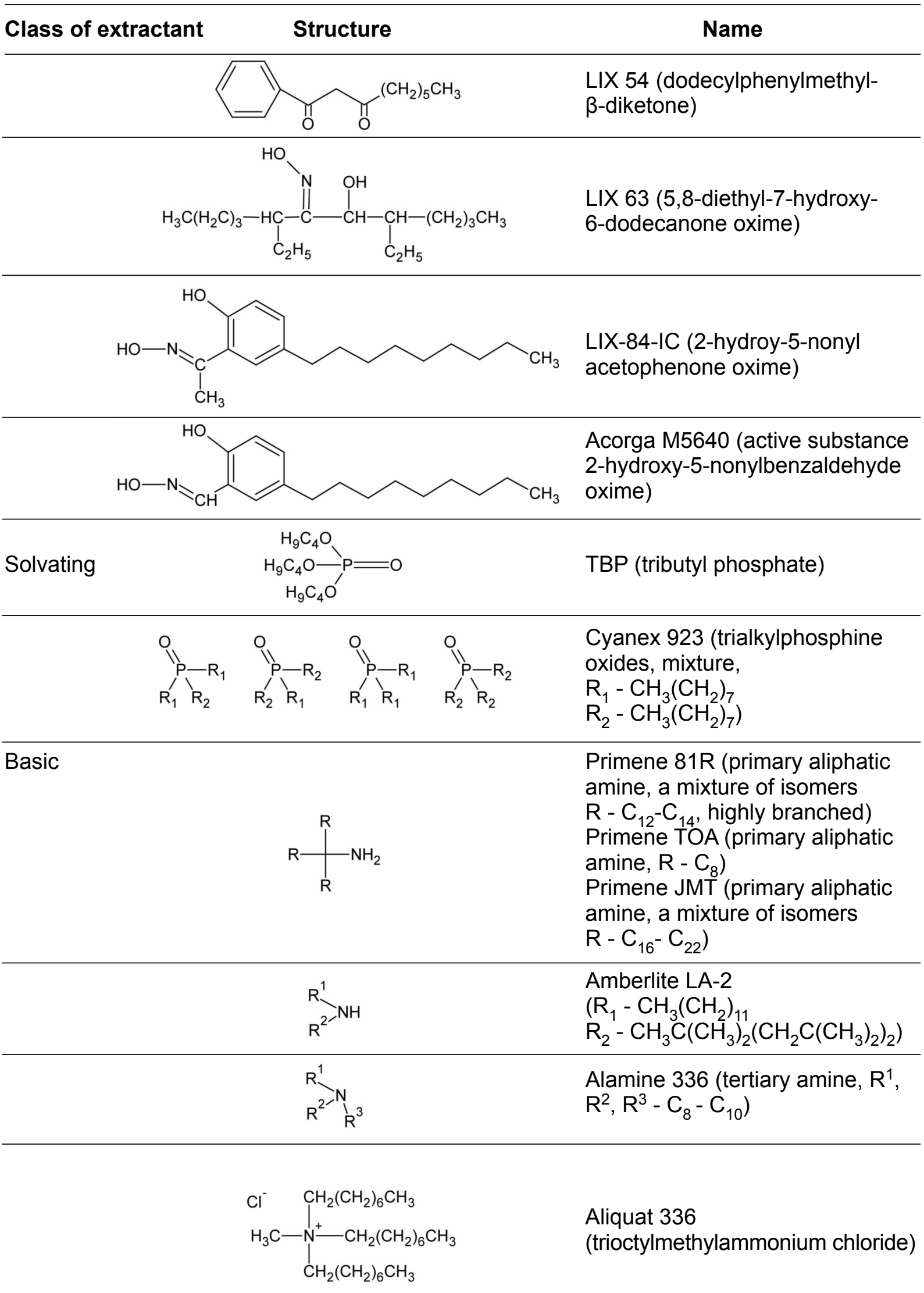


Well-known mechanisms of reaction and mass transport, wide range of technical and technological solutions, the possibility of metal separation from low concentrated solutions or from deposits of unconventional composition, high purity of products, metal recovery from waste streams, recycled materials, possibility of by-product recovery, and a tendency to build small plants are the most important features that still determine the attractiveness of the liquidliquid extraction for separation of metal ions. In the contrary, as disadvantages of extraction should be mentioned the following: difficulties in the comprehensive recovery of various metals, degradation of the organic phase during extraction, impurity transport to the interface, a fire hazard - the use of hydrocarbon solvents, the toxicity of solvents and extractants, the problem of scaling up from the laboratory - to the industrial scale.

The further development of extraction is believed to tend towards the search for new extractants or synergistic mixtures based on the extractants previously used (so-called "SSX" - synergistic SX or "DSX" - synergistic direct SX $\left.{ }^{[4]}\right)$, new applications for extraction (such as recovery of metals or acids from secondary sources), use of hybrid systems (e.g. combination of extraction and membrane techniques), replacing volatile solvents or extractants with ionic liquids, the need for separation of metals from less concentrated raw materials of complex composition. In the latter case hydrometallugical methods are much more economical and efficient than pyrometallurgical ones. The basis for the further development of extraction seems to be a continuous cooperation between science and industry (Fig. 1) to find the best solutions both economically and ecologically.

A progressive development of chelating extractants for copper SX is a good example of continuous improvement and cooperation between industry and science. For the last fifty years reagent properties have been changed to improve extractive strength, $\mathrm{Cu} / \mathrm{Fe}$ selectivity, kinetics, stability, versatility, and reduce crud formation, coming, finally, to tailor made extractants that meet specific conditions of the plant ${ }^{[5]}$.

The aim of this paper is to present some examples of extraction applications in recent years, both in industrial plants and laboratory studies.

\section{SOLVENT EXTRACTION IN INDUSTRY}

The largest extraction plants for metal separation from primary sources are located in Africa, the Americas and Australia. The economic crisis of the year 2008/2009 led to discontinuity of many SX plants operation, as a result of dramatic decrease in prices of strategic metals. However, now they start to continue their production. Some plants which commenced in the $21^{\text {st }}$ century applying SX circuit for metal recovery are listed in table II.

SX is still considered an economical route for the production of high-quality cobalt cathode. Thus, one of the newest projects using extraction for separation of cobalt, copper and zinc is the El Boleo in Mexico[11-16]

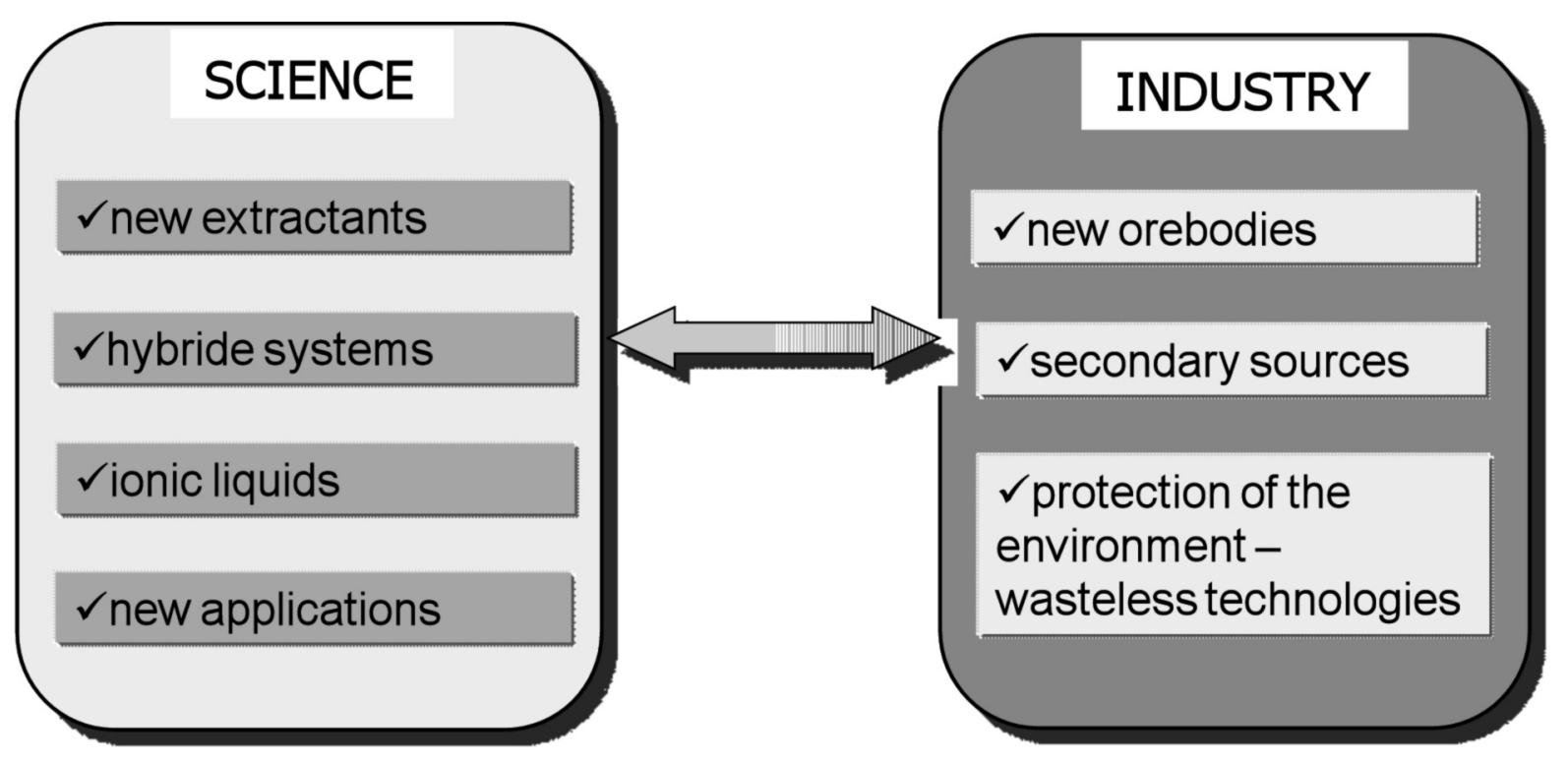

Figure 1. Present trends in extraction development.

Figura 1. Tendencias actuales en el desarrollo de los proceso de extracción de metales. 
Table II. Some recently commissioned plants using SX for metal ion separation from primary ores

Tabla II. Algunas plantas industriales que utilizan la extracción con disolventes para la separación de metales provenientes de materias primas

\begin{tabular}{|c|c|c|c|c|}
\hline $\begin{array}{l}\text { Name of the } \\
\text { project }\end{array}$ & Place & Yield & $\begin{array}{c}\text { Year of } \\
\text { commissioning }\end{array}$ & Ref. \\
\hline Luita (Comec) & $\begin{array}{l}\text { Democratic } \\
\text { Republic of Congo }\end{array}$ & $\begin{array}{l}100000 \text { t Cu/year } \\
12000 \text { t Co/year }\end{array}$ & 2008 & {$[6,7]$} \\
\hline Etoile Mine & Australia & 24000 t Cu/year & 2007 & [8] \\
\hline Kounrad & Kazakhstan & 10000 t Cu/year & 2012 & [9] \\
\hline Riochilex Spence & Chile & 200000 t Cu/year & 2006 & [10] \\
\hline El Boleo & Mexico & $\begin{array}{l}56000 \mathrm{t} \mathrm{Cu} / \text { year } \\
\sim 2000 \mathrm{t} \mathrm{Co/y} \\
25000 \mathrm{t} \mathrm{Zn} / \text { year as } \\
\mathrm{ZnSO}_{4} \cdot \mathrm{H}_{2} \mathrm{O} \\
\text { Mn as manganese } \\
\text { carbonate }\end{array}$ & $2010-2013$ & {$[11-16]$} \\
\hline NorthMet & USA & $\begin{array}{l}72000 \text { t Cu, } \\
16000 \text { t Ni, } \\
750 \text { t Co, } \\
60000 \text { oz Pt, } \\
162000 \text { oz Pd, } \\
37000 \text { oz Au }\end{array}$ & 2006 & {$[13,17-19]$} \\
\hline Goro Nickel & New Caledonia & $\begin{array}{l}60000 \text { t Ni/year } \\
\sim 5000 \text { t Co/year }\end{array}$ & 2013 & [20-22] \\
\hline Murrin Murrin & Australia & $\begin{array}{l}40000 \text { t Ni/year } \\
2500 \text { t Co/year }\end{array}$ & 1999 & [23] \\
\hline Skorpion Zinc & Namibia & 150000 t Zn/year & 2001 & [24-32] \\
\hline
\end{tabular}

from a mixed sulphide/oxide deposit. A synergistic mixture of Versatic 10 acid and LIX 63 in Orfom SX80 CT (mixture of naphtalene and ethylbenzene) is employed for copper and zinc separation from manganese, the key issue of El Boleo. Co(II) and $\mathrm{Zn}$ (II) are recovered in $99 \%$ using the so called CSIRO DSX system including 3 extraction stages, 2 scrubbing stages, 4 stripping stages, while almost $100 \%$ rejection of manganese is noticed. Zinc is perfectly separated from cobalt (Zn:Co ratio equals 4000:1) by SX with $30 \%$ Cyanex 272 at $\mathrm{pH}$ 2.6-2.9. Afterwards, cobalt is extracted from the raffinate from zinc SX using $30 \%$ Cyanex 272 at pH 5.2-5.5 [13]. Commercial LIX 63 contains aliphatichydroxyoxime in both anti and syn isomeric forms (a 3:2 ratio) but only anti isomer plays a crucial role in metal complexing ${ }^{[33-35]}$. Thus, the economy of the SX process can be improved by increase in anti isomer ratio in the organic phase. The most important technological problem so far is the degradation, and thus the loss, of LIX 63 oxime in the process ${ }^{[34}$ and 35$]$.

NorthMet mining plant in northern Minnesota plans to treat base and precious metal sulphide concentrates containing copper, nickel, cobalt, platinum, palladium, gold and silver. The concentrate is produced in the PLATSOL process-a high temperature $\left(\sim 210^{\circ} \mathrm{C}\right)$ pressure chloride-assisted leaching. The flowsheet of NorthMet includes high temperature leaching, solid-liquid separation and washing, PGM/Au precipitation, neutralization and Cu SX-EW to produce, finally, copper cathode ${ }^{[13]}$. 
The process is quite complicated because of the large number of metal ions to be separated; its simplified scheme (including three SX circuits) is presented in figure 2 .

In the next stages, nickel and cobalt are recovered from part of the $\mathrm{Cu}$ SX raffinate $(25 \%)$ by neutralization, first and second stage iron/aluminium removal, residual copper removal by precipitation as a sulphide, first stage $\mathrm{Ni} / \mathrm{Co} / \mathrm{Zn}$ precipitation with magnesia, second stage $\mathrm{Ni} / \mathrm{Co} / \mathrm{Zn}$ precipitation with lime, and then magnesium removal with lime to produce a mixed hydroxide of nickel, cobalt and zinc. It is possible to produce purified hydroxides by SX of copper and zinc (the option shown in Figure 2). The application of SX to obtain copper or cobalt, nickel and zinc will depend on the market requirements.

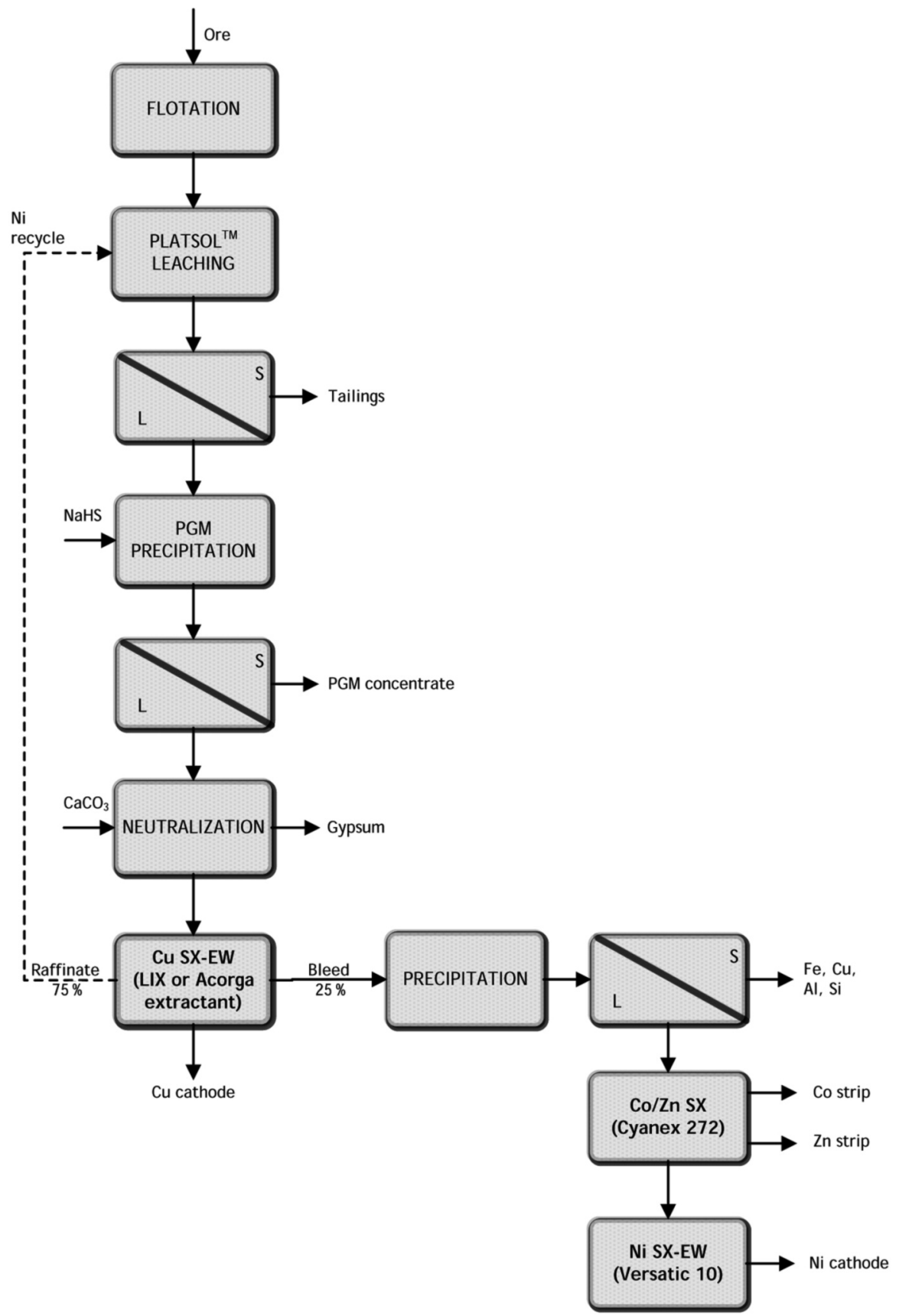

Figure 2. Schematic flowsheet of NorthMet process for PGM, copper, nickel, zinc and cobalt recovery ${ }^{[19]}$.

Figura 2. Esquema del diagrama de flujo del proceso NorthMet para la recuperación de metales del grupo del platino cobre, níquel, zinc y cobalto[19]. 
First SX circuit realized to produce copper includes three counter-current extraction, one scrubbing and two stripping (with spent electrolyte from the electrowinning) stages. Both extractants tested in pilot scale, i.e. 35 \% Acorga M5640 or 35 \% LIX 973NS LV in Orfom CX80CT (as a diluent) performed well, and recovered $95 \%$ of $\mathrm{Cu}^{[18 \text { and } 19]}$.

The second SX circuit for bulk Co/Zn extraction is planned in four stages at $\mathrm{pH} 5.0-5.5$ and $55^{\circ} \mathrm{C}$ (better cobalt extraction and magnesium displacement in the organic phase) with an organic phase containing $5 \%$ Cyanex 272 in Orfom SX80CT. $\mathrm{Ni}$ remains in the raffinate, and can be precipitated as $\mathrm{Ni}(\mathrm{OH})_{2}$. Cobalt will be stripped with sulphuric acid in three stages at $\mathrm{pH} 3$ and $45^{\circ} \mathrm{C}$, before zinc stripping in two stages at $\mathrm{pH}<1$ and $40^{\circ} \mathrm{C}[13,18$ and 19$]$. The efficiencies of cobalt and zinc extraction are greater than 96 and $99.9 \%$, respectively. For both SX circuit operations no crud formation was noted.

Finally the plant was planned to produce the following products: copper cathode of LME Grade A quality, gold and PGM precipitate for toll processing, mixed hydroxide product containing nickel-copperzinc or separate purified nickel and copper hydroxide and either a zinc hydroxide or a zinc strip solution, synthetic gypsum. The pilot scale tests were performed in 2005 and $2006^{[13]}$. However, in 2011 the project was revised and (to reduce the investment costs) some changes were introduced, namely, elimination of SX circuits and replacement of cathode copper production with concentrates of copper, nickel, cobalt and precious metals.

Over $30 \%$ of the global output of refined copper is produced at SX-EW plants across the world and the development of hydrometallurgical copper production is expected in treatment of low quality ores particularly in countries suffering a negative balance between the copper production and consumption $^{[36]}$. Riochilex Spence (2006), El Boleo (2010-2013), Chuquicamata Oxide Plant Train A (start-up in 2008), Franke (2009), Assarel (2010), Tia María (start-up planned for 2012) and Caserones (2013) are only some examples of recently commissioned SX installations for copper

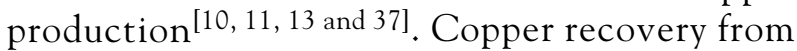
complex chloride solution in El Boleo process is realized by selective SX with oxime $20 \%$ LIX 664N, the technology adapted from Chilean mining plants. An example of an innovative design of copper SXEW plant is Riochilex Spence mine that processes oxide and sulphide ore by open pit mining, three stage crushing, drum agglomeration, heap leach, solvent extraction and electrowinning. The important thing is that the ores are treated separately, i.e. by sulphuric acid leaching (oxide) and bacterial leaching (sulphide). As a consequence, different PLS are produced that are separately extracted in a Spence SX plant in four trains, operating independently and designed with the reverse flow technology. One train scheme is shown in figure 3.

The SX process includes the six following stages: two sulphide stages (E1 fed by sulphide PLS and E2 producing the sulphide raffinate, two oxide stages (E1P, E2P - in parallel with the sulphide stages), one stripping stage (S1), and one washing stage (W). A mixture of salicylaldoxime and ketoxime (e.g. LIX $860 \mathrm{~N}$-LIX 84 I) in a high flash-point, kerosene-based diluent is used as an organic phase. Chloride entrainment to the stripping stage is minimized by the sequence of cleaning the loaded organic phase from the oxide stage (E1P) in the following sulphide stages (E2 and E1), and in the washing stage (W).

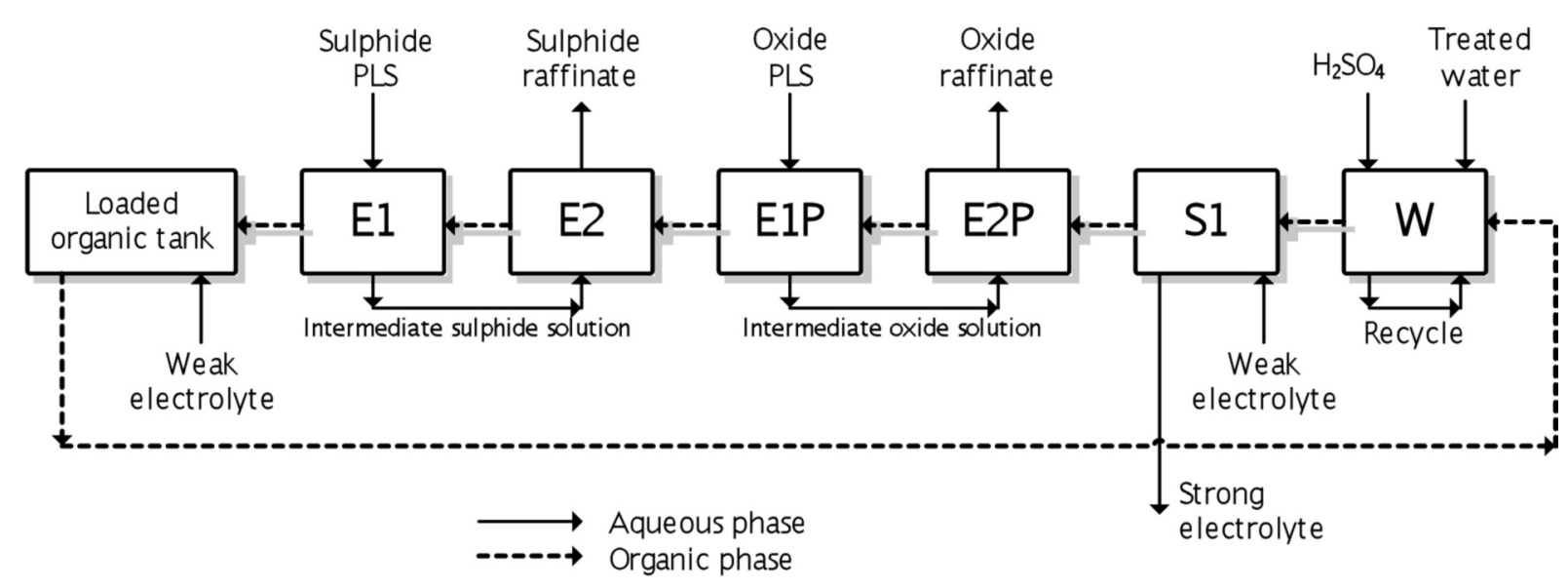

Figure 3. Scheme of Spence SX plant for copper separation from PLS ${ }^{[10]}$.

Figura 3. Esquema de la planta de extracción con disolventes Spence para la separación de cobre de disoluciones de lixiviación ${ }^{[10]}$. 
The reduction of chloride concentration in the reach electrolyte is crucial for the quality of electro-winning process. Another important problem-fire hazardfaced by SX plants was minimized in Spence by application of fibre-reinforced polymers for mixersettler construction, and HDPE for piping. Moreover, monitoring of the organic level and equal overflows to avoid air entrainment and spillages, avoidance of warming-up the organic, earthing at various points of the circuit, water reserves for fire events with gravity flow to SX, high expansion foam system are the fire prevention means ${ }^{[10]}$.

Besides the above and other large SX operations, nowadays there are twenty five $\mathrm{Cu}-\mathrm{SX}$ plants of a medium-small size currently operating in Chile (Table III). From a copper production point of view, small-medium size means that the current capacity runs from 3000-30000 t/year of copper cathode. All in all, Chilean copper SX-electrowinning operations are the responsible of the production of more than $2 \times 10^{6} \mathrm{t} /$ year of copper cathode.

As described elsewhere ${ }^{[38]}$, these plants work in various configurations not only in the number of extraction/stripping stages but also in the configuration used in the extraction circuit: series, triple series, triple parallel, interlaced, etc. Since some of them use seawater in the leaching stage, a wash stage was introduced in the SX plant to eliminate the entrained chloride ions in the organic phases, which are definitively harmful in the electrowinning plant.

With respect to the copper content in the pregnant solution, these plants are divided between those which works with less than $4 \mathrm{~g} / \mathrm{dm}^{3}$, and the others which feed the SX operation with solutions containing more than $4 \mathrm{~g} / \mathrm{dm}^{3}$ copper. The $\mathrm{pH}$ values of the pregnant leach solution vary between 1.2 and 2.5. With respect to the extractant selection, most of the plants uses a ketoxime/aldoxime blend according to their operational conditions, with few plants (a total of six) using modified aldoximes and just two (one each) using pure ketoxime or aldoxime extractants as reagents for copper.

Despite further considerations, it can be concluded that the technology runs successfully and it is economically profitable in these Chilean smallmedium size copper-SX plants.

The success of the $\mathrm{Cu}$-SX operation, besides its coupling with leach and electrowon operations, is based on the formation of a very stable $\mathrm{Cu}$ (II)-oxime chelate compound in the extraction process and at short elapsed times, and at the same time easy to strip with sulphuric acid solutions. Currently, two basic oximes formulations are being used in $\mathrm{Cu}-\mathrm{SX}$ plants: aldoximes and ketoximes, whose generic structures are given in figure 4.

Moreover, in figure 5 is represented the structure of a typical 2:1 salicylaldoxime:copper(II) chelate. The stability of such a compound is due, besides other considerations, to the donation of a pair of electrons (indicated as arrows in the figure) from each one of the nitrogen atoms to the copper(II) ion, and thus forming a very stable six members ring configuration.

However, previously reported environmental benefits of hydrometallurgical processing seem to

Table III. Selected small-medium copper SX plants operating in Chile

Tabla III. Plantas de tamaño mediano-pequeño operativas en Chile y que utilizan la extracción con disolventes para la recuperación del cobre

\begin{tabular}{|c|c|c|}
\hline Plant & Stages & $\begin{array}{l}\text { Cu cathode } \\
\text { t/year }\end{array}$ \\
\hline lymet-Copper plant & 3extractio & 3000 \\
\hline & & \\
\hline -Biocobre & 2 & 0 \\
\hline Bronces & $2 \mathrm{ex}$ & \\
\hline ulfuros BL & $2 e x$ & \\
\hline Codelco-Salvador & 2extraction+stripping+wash & 30000 \\
\hline \multicolumn{3}{|c|}{$\begin{array}{l}\text { Other plants: Enami-Taltal, Trinidad-Nora plant, San Geronimo-San Lorenzo, } \\
\text { Enami-Minera Cruz, Cerro Dominador-Sta. Margarita, Cenizas-Oxide plant, } \\
\text { Enami-EI Salado, Enami-A. Matta, Cemin-Dos Amigos, Cerro Negro-Oxide, } \\
\text { Anglo-El Soldado, Sierra Miranda, Cemin-Amalia plant, Codelco-El Teniente, } \\
\text { HMC-Haldeman Sagasca, TECK-CD. Andacollo, Vale-Tres Valles, Mantos } \\
\text { de la Luna, QuadraFNX-Franke. }\end{array}$} \\
\hline
\end{tabular}



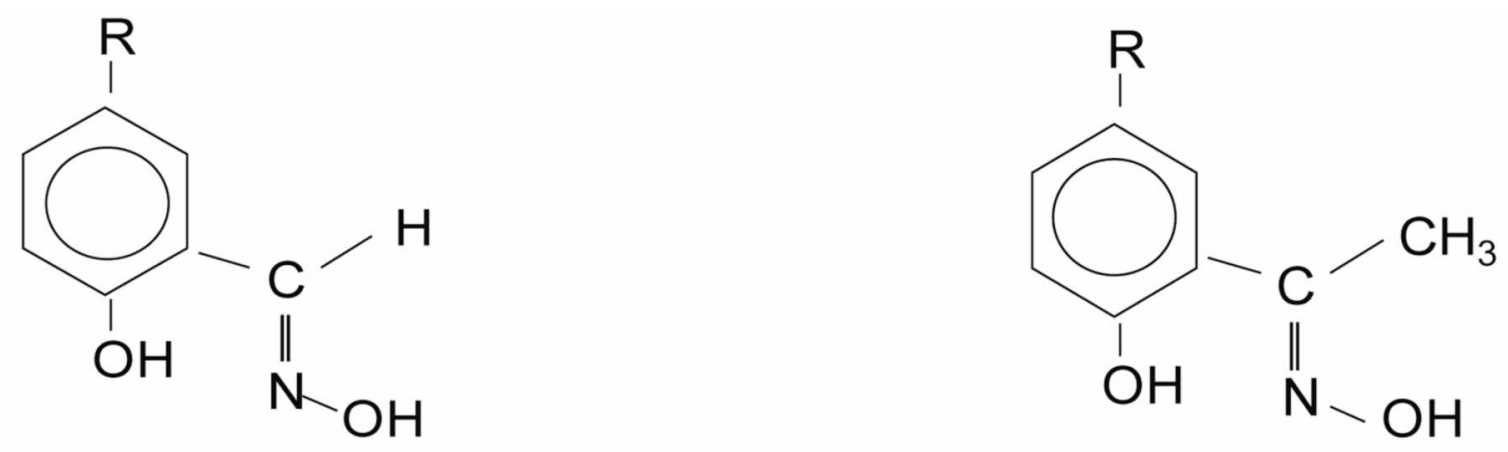

Figure 4. Basic structures of aldoximes (left) and ketoximes (right).

Figura 4. Estructuras generales de las aldoximas (izquierda) y cetoximas (derecha).

diminish, i.e. at present times, in terms of $\mathrm{CO}_{2}$ emissions, copper SX-EW plants produce roughly 2.8 tons of $\mathrm{CO}_{2} /$ ton of copper electrowon against 2.9 tons of $\mathrm{CO}_{2}$ /ton of copper electrorefined.

The African deposits of Ni/Co (e.g. DCR Copper Belt, Chambishi Metals PLC Zambia) face a serious problem of manganese presence resulting in its transfer to the electrolyte and its oxidation, causing further degradation of the organic phase. For this reason manganese is removed, for example, by oxidation with air $/ \mathrm{SO}_{2}$ mixture or SX with DEHPA. After this step, hydroxyoximes are proposed as selective extractants of copper in the presence of cobalt, while Cyanex 272 is used for separation of cobalt from nickel. Finally, DEHPA is employed for $\mathrm{Zn}(\mathrm{II})$ extraction ${ }^{[24]}$. Additional problem that occurs during the separation of cobalt from nickel results from oxidation of hydrocarbons to carboxylic acids catalyzed by cobalt, and reduction in the selectivity of these two metals separation ${ }^{[39]}$.

Australian Murrin Murrin Operations' separates zinc and cobalt from the nickel rich, sulphate-based solution in two SX circuits. Cyanex 272 is used as an active extractant, TBP as a phase modifier and Shellsol 2046 as a diluent ${ }^{[23]}$. As it has appeared during SX circuit operation, some reactions between Cyanex 272

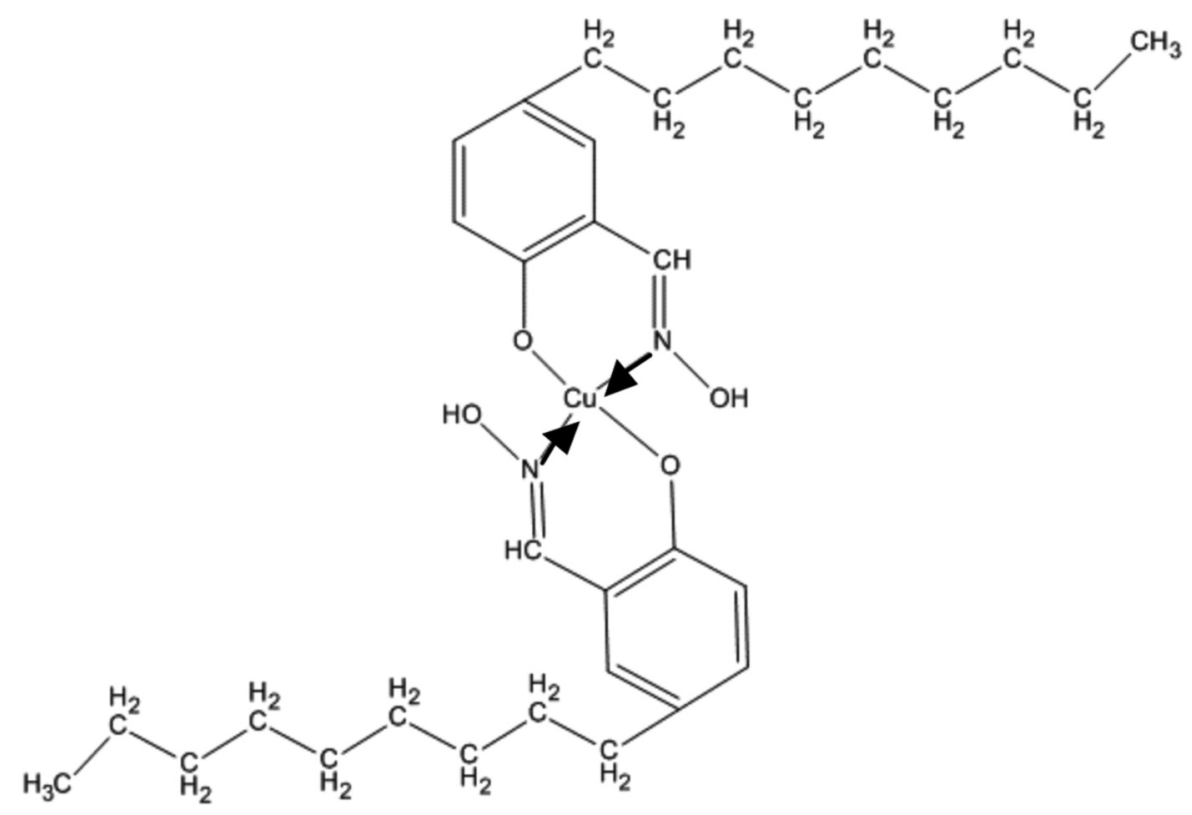

Figure 5. 2D dimensional view of generic 2:1 salicylaldoxime: $\mathrm{Cu}(\mathrm{II})$ chelate.

Figura 5. Estructura 2D del quelato 2:1 formado entre una salicilaldoxima y el Cu(II). 
and TBP take place, and organic impurities are formed that potentially could increase mineral acids entrainment.

As sulphide nickel ores are becoming hardly accessible, nickeliferous laterite (most of the world's known nickel and cobalt resources) will be probably the predominant source of new nickel and cobalt in the future. However, treatment of laterite ores involves operation of large volumes of relatively dilute leach solutions containing except from cobalt and nickel, significant quantities of manganese and magnesium ${ }^{[18]}$. A solution that uses directly the partially neutralized leach liquor is solvent extraction, and will be soon applied for nickel production in the world largest mining project in New Caledonia. The process (called Goro process) involves nickel, copper and zinc extraction with Cyanex 301, stripping of metal ions with hydrochloric acid, removal of zinc by ion-exchange, cobalt recovery by tertiary amine extractant to produce, finally, by pyro-hydrolysis, nickel oxide. Though low reagent and energy costs are the advantageous features of the Goro process, it is important to emphasise that the extractant is degraded by metal-catalysed oxidation by air ${ }^{[21]}$. Therefore, Bateman company designed 22 extraction pulsed columns (an alternative to conventional SX mixer-settlers) that will work in an inert atmosphere to avoid Cyanex 301 decomposition $^{[40]}$.

\subsection{Non-sulphide zinc ores-Skorpion Zinc plant, case study}

An interesting and successful example of liquid-liquid extraction application for processing of unconventional orebody is the Skorpion Zinc plant located in the Namib Desert in southern Namibia. In the $70 \mathrm{~s}$ zinc was discovered in the form of oxide ores consisting of such minerals as sauconite, smithsonite, hemimorphite and hydrozincite ${ }^{[31]}$. However, at that time their processing was considered unprofitable. Again these deposits, assessed in 2000 at nearly 20 million tons with an average zinc content of $10.1 \%$, became interesting for investors in the late $90 \mathrm{~s}$ of the XX century. In January 2001 the mine was completed with the installation of zinc ore processing for SHG (Special High Grade) with high purity, containing min. $99.995 \% \mathrm{Zn}$.

The capital cost of this project came to $\$ 454$ million ${ }^{[31]}$, and the resulting installation is the first and the largest in the world using industrial-scale extraction- electrolysis (SX-EW, Solvent ExtractionElectro Winning) of zinc from the leach solutions of primary sources. Schematic representation of zinc ore processing in the Skorpion Zinc plant is shown in figure 6.

Zinc processing includes the following steps: an atmospheric leaching with sulphuric acid, SX, EW, melting and casting of the metal. Shredded bed is homogenized and wet milled, and then leached with sulphuric acid in tanks at atmospheric pressure and elevated temperature.

Neutralization with lime of pregnant leach solution (PLS) results in precipitation of impurities such as iron, aluminium and silicon. This precipitation after thickening is acidified to recover the co-precipitated zinc. Sludge and other solid wastes are removed by filtration. The clarified PLS is sent to the extraction circuit (SX) to remove by scrubbing chlorides and fluorides that could disturb the electrolysis step. In SX circuit zinc is extracted with $40 \%$ DEHPA in a partially aromatic diluent Escaid 100. Zinc is deposited by electrolysis on aluminium cathodes. Once melted, SHG zinc is cast ${ }^{[25]}$.

Metal ions such as copper, nickel, cobalt and cadmium are removed from the first filtrate by cementation with zinc dust. Halides and magnesium in the second filtrate are precipitated as basic zinc sulphate $(\mathrm{ZnO})_{3} \mathrm{ZnSO}_{4}$. Afterwards, zinc is recycled in the form of precipitation to the process as a neutralizing agent.

Till the end of 2004 Skorpion Zinc plant reached $95 \%$ of its capacity, and the production of almost 120000 tons of zinc annually. In 2005, production increased by $11 \%$ to more than 130000 tons of zinc (despite the warehouse fire in February 2005), in 2011 amounted to 150000 tons.

Extraction step (Fig. 7) is based on a technology known as Modified Zincex ${ }^{\mathrm{TM}}$ Process (MZP) developed by Técnicas Reunidas. The process is carried out at $40-45^{\circ} \mathrm{C}$, the phase ratio during the extraction o/w equals 1-1.5. At this stage, pregnant leach solution of zinc, which includes also such impurities as manganese, magnesium, chlorine, calcium, copper, nickel, cadmium, aluminium, silicon, fluor, cobalt and iron, is purified and enriched. $40 \%$ solution of DEHPA (in the reaction marked as $\mathrm{RH}$ ) extracts zinc(II) according to a cation exchange reaction:

$$
\mathrm{Zn}_{(\mathrm{w})}^{2+}+2 \mathrm{RH}_{(\mathrm{o})} \Leftrightarrow 2 \mathrm{H}_{(\mathrm{w})}^{+}+\mathrm{ZnR}_{2(\mathrm{o})}
$$

As a consequence of extraction, protons are released to the aqueous phase; therefore it is important to control and maintain constant $\mathrm{pH}$ during the extraction in the range 1.8-2.

After three steps of extraction (E) Zn(II) loaded organic phase is scrubbed (SC) with demineralized water and spent electrolyte to wash out co-extracted impurities, and replace them with $\mathrm{Zn}(\mathrm{II})$. Afterwards, $\mathrm{Zn}(\mathrm{II})$ is stripped (S) from the organic phase with spent electrolyte according to the following reaction:

$$
2 \mathrm{H}_{(\mathrm{w})}^{+}+\mathrm{ZnR}_{2(\mathrm{o})} \Leftrightarrow \mathrm{Zn}_{(\mathrm{w})}^{2+}+2 \mathrm{RH}_{(\mathrm{o})}
$$

In the last stage of the organic phase regeneration (R) $\mathrm{HCl}$ is used to remove $\mathrm{Fe}$ (III) co-extracted during the previous stages of SX process. 


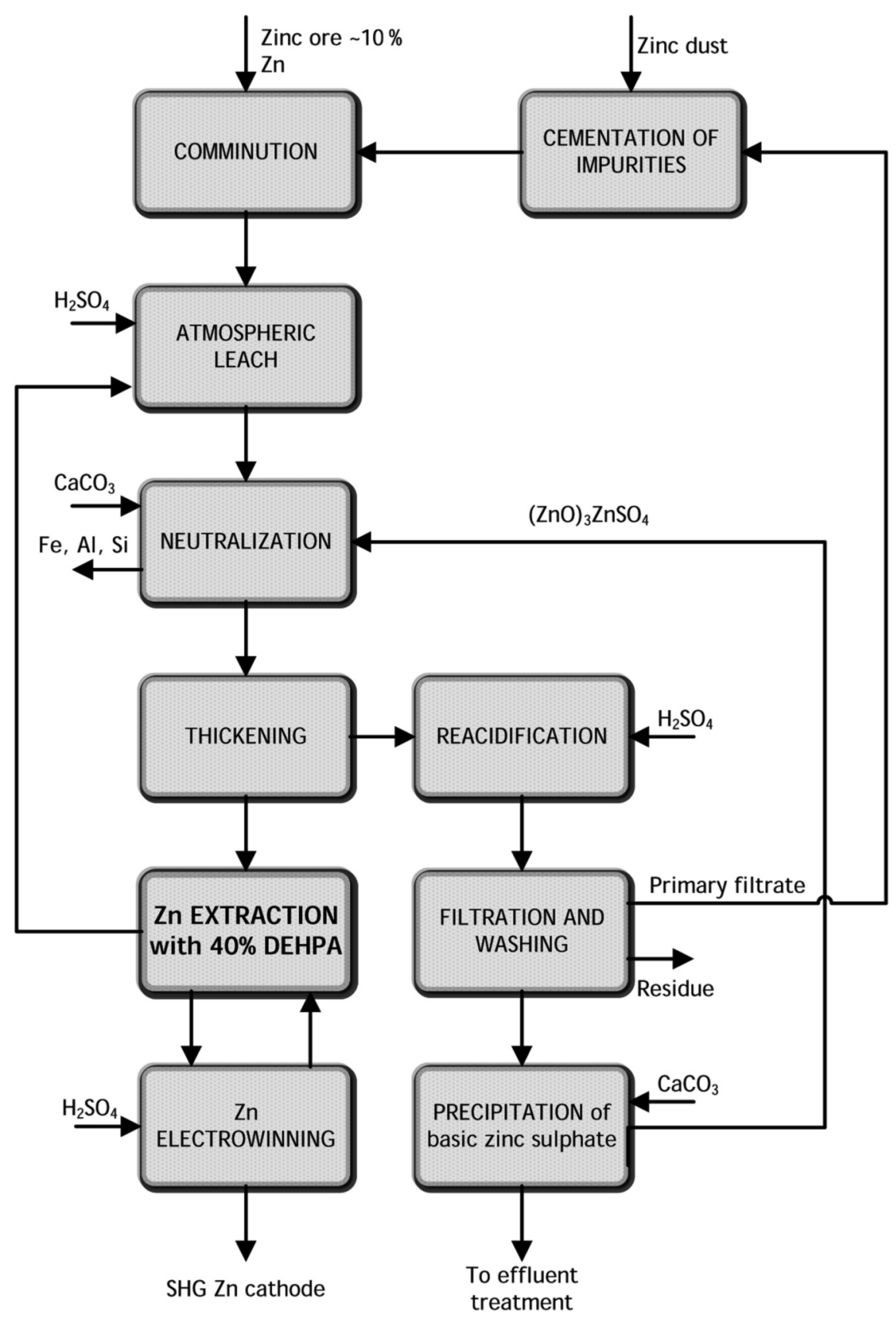

Figure 6. Schematic representation of zinc ore processing in the Skorpion Zinc plant ${ }^{[25-32]}$.

Figura 6. Representación esquematica del procesado del mineral de zinc en la planta Skorpion ${ }^{[25-32]}$.

Among the advantages resulting from the use of DEHPA as an extractant should be mentioned the following: rejection of metal halides and the accompanying metal ions-harmful for electrolysis stage, very high selectivity in relation to zinc, concentration of the diluted solution after leaching $\left(38 \mathrm{~g} / \mathrm{dm}^{3} \mathrm{Zn}(\mathrm{II})\right)$ to the concentrated electrolyte $\left(100 \mathrm{~g} / \mathrm{dm}^{3} \mathrm{Zn}(\mathrm{II})\right)$. In addition, neutralization of the raffinate and the electrolyte is unnecessary, because these streams are reused for leaching or stripping. Residues of extractant are removed using flotation and adsorption on activated carbon.

Start-up and operation of the plant resulted in appearance of various problems associated with the loss of the organic phase, the transfer of impurities to the electrolysis stage or co-extraction of other metal ions. Significant problems, risks resulting from them, and also the solutions applied are presented in table IV. 


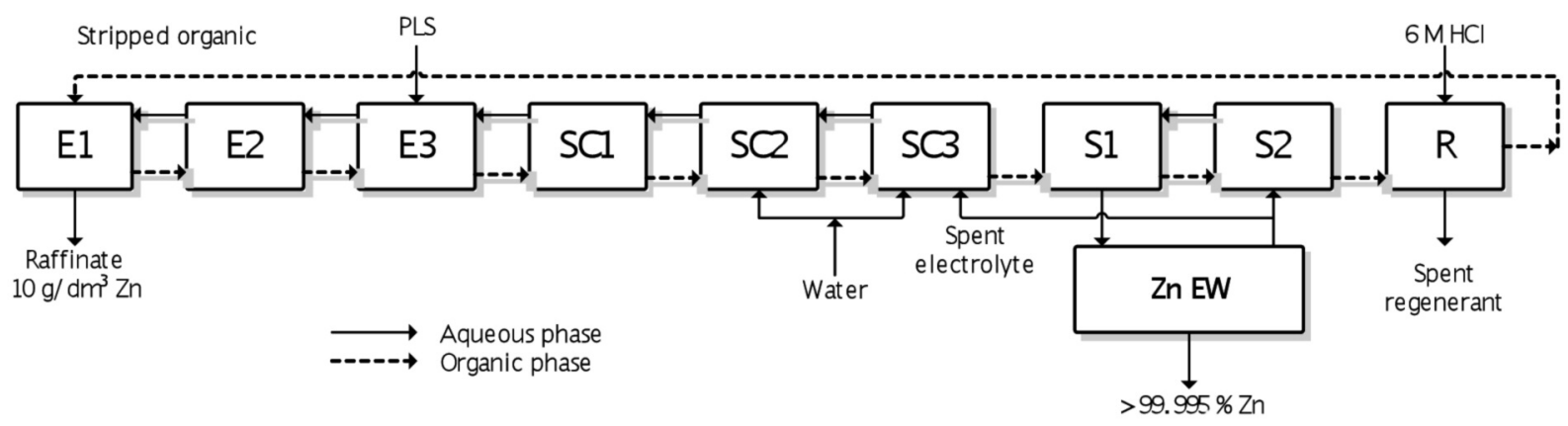

Figure 7. Scheme of the Skorpion Zinc SX circuitt25-32].

Figura 7. Esquema del circuito de extracción con disolventes de la planta Skorpion[25-32].

Table IV. Problems appearing during the Skorpion Zinc plant operation ${ }^{[26-32]}$

Tabla IV. Problemas aparecidos en la operación de la planta Skorpion ${ }^{[26-32]}$

\begin{tabular}{|c|c|c|}
\hline Problem & Risk & Solution \\
\hline Loss of the organic phase & $\begin{array}{l}\text { - decrease in the organic } \\
\text { phase volume } \\
\text { - reduction in the organic } \\
\text { phase capacity } \\
\text { - risk of fire }\end{array}$ & $\begin{array}{l}\text { - application of closed tanks } \\
\text { conitoring of other metal } \\
\text { earth metals) } \\
\text { - selection of appropriate } \\
\text { pumping rate }\end{array}$ \\
\hline $\begin{array}{l}\text { Transfer of impurities } \\
\text { to electrolysis } \\
\text { (e.g. } \mathrm{Ni}(\mathrm{II}), \mathrm{Co}(\mathrm{II}))\end{array}$ & $\begin{array}{l}\text { - contamination of the final } \\
\text { product } \\
\text { - change in morphology of } \\
\text { deposited zinc } \\
\text { - formation of "sticky" zinc } \\
\text { - generation of } \mathrm{H}_{2} \text {-fire risk } \\
(2005 \text { and } 2006)\end{array}$ & $\begin{array}{l}\text { - Mn addition to electrolyte } \\
\text { in EW stage } \\
\text { - control of liquid interface } \\
\text { level in settlers } \\
\text { - frequent control of impurities } \\
\text { concentration }\end{array}$ \\
\hline $\begin{array}{l}\text { Co-extraction of } \\
\text { Fe(III) and rare earth } \\
\text { elements (REE) }\end{array}$ & $\begin{array}{l}\text { - decrease in extractant } \\
\text { capacity }\end{array}$ & $\begin{array}{l}\text { - additional stage of the } \\
\text { organic phase scrubbing } \\
\text { - elaboration of REE separation } \\
\text { from the organic phase } \\
\text { - continuous control of the } \\
\text { extractant concentration }\end{array}$ \\
\hline $\begin{array}{l}\text { Formation of colloidal } \\
\text { silica (large content of } \mathrm{Si}, \\
\text { about } 25 \% \text { ) }\end{array}$ & $\begin{array}{l}\text { - stabilization of emulsions } \\
\text { during extraction } \\
\text { - unfavourable influence on } \\
\text { phase separation kinetics } \\
\text { in settlers }\end{array}$ & $\begin{array}{l}\text { - more effective control of } \\
\text { pregnant leach solution } \mathrm{pH}\end{array}$ \\
\hline $\begin{array}{l}\text { Formation of crud } \\
\text { at organic/water interface }\end{array}$ & $\begin{array}{l}\text { loss of the organic phase } \\
\text { transfer of impurities to } \\
\text { further stages of the process }\end{array}$ & $\begin{array}{l}\text { - application of pinned-bed } \\
\text { clarifier for removal of solid } \\
\text { particles } \\
\text { - application of centrifuge for } \\
\text { the organic phase removal } \\
\text { - reduction of fluxes }\end{array}$ \\
\hline
\end{tabular}


Losses of the organic phase are caused by evaporation from the settlers (their surface $375-625 \mathrm{~m}^{2}$ ), formation of the mist or crud at the interface of the organic and aqueous phases. Organic replacement accounts for about $60 \%$ of the total costs of SX maintenance, therefore reduction to a minimum in this cost is an important issue.

Excessive aeration of the organic phase promotes the crud formation at the interface, and can be reduced by automating the operation of mixer-settlers and pumps, controlling the level of the liquid surface in settlers, and fitting a siphon control valve. In addition, DEHPA extraction capacity is reduced by the accumulation of rare earth elements (REE) and other trivalent metals (mainly iron) in the organic phase. Transfer of some impurities to the EW electrolyte during the extraction results from degradation of the organic phase (presence of $\mathrm{Co}(\mathrm{II})$ causes the catalytic oxidation of the diluent), and the entrainment of particles during the extraction and accumulation at the interface of the organic and aqueous phases. Colloidal silica formation is enhanced by the changes in $\mathrm{pH}$ and temperature during leaching, neutralization and extraction steps.

The solutions applied so far have brought many benefits and improved significantly the process performance and safety. Skorpion Zinc plant is considered to be one of the lowest cost zinc producers in the world ${ }^{[41]}$. At the same time, the improvement of the running Skorpion Zinc plant is an ongoing process. One of the issues to be solved is a recovery of the rare earth metals from the organic phase, and separation in a form suitable for further processing or sale. Some attempts of the design of REE circuit have been made by Técnicas Reunidas ${ }^{[42]}$. After laboratory scale research direct stripping of REE from organic DEHPA with fluoride salts, and also hydrofluoric acid, seems to be the most advantageous operation resulting in formation of easy to recover precipitation that contains $25-40 \%$ Y, 8-15 \% Yb, 3-5 \% Er, 1-2 \% Sc and $0.01-0.05 \% \mathrm{U}$. The recovery of REE will make MZP process more economical and efficient (longer performance of the organic phase).

However, alternatives are given in the form of REE stripping from DEHPA-loaded phases using sulphuric acid solutions ${ }^{[43]}$. From this investigation, it is concluded that it is possible to removal yttrium, erbium and ytterbium from the zinc-stripped organic phase of Skorpion Zinc plant, if the process is designed under the following specifications: sulphuric acid concentration of 5-7 M, O:A ratio of $1: 2$ and temperature around $50^{\circ} \mathrm{C}$. The apparent order of the stripping abilities is as follows $\mathrm{Y}=\mathrm{Er}>\mathrm{Yb}$.

Moreover, and from the chemical point of view, the equilibrium which represents the extraction/stripping reactions of these elements with
DEHPA and acidic solutions as strippants, can be written as ${ }^{[44]}$ :

$$
\mathrm{RE}_{(\mathrm{w})}^{3+}+3\left(\mathrm{H}_{2} \mathrm{~L}_{2}\right)_{(\mathrm{o})} \Leftrightarrow \mathrm{REL}_{3}-3 \mathrm{HL}_{(\mathrm{o})}+3 \mathrm{H}_{(\mathrm{w})}^{+}
$$

where RE represents the various rare earths elements.

\subsection{Trends in caesium solvent extraction-case study}

A considerable amount of High Level Waste (HLW) is produced during the reprocessing process. This waste consists of a number of radioactive and nonradioactive elements, which retains an important amount of the radiotoxicity of the original spent fuel. ${ }^{137} \mathrm{Cs}$, together with ${ }^{90} \mathrm{Sr}$, contribute with a considerable part of the heat load and radiation of HLW, thus the removal of Cs(I) from such effluents (HLW, tank wastes and industrial radiation sources) may be considered as a primary target. Considering which separation technology is the best to achieve this goal, solvent extraction seems to have unique advantages over ion exchange and even crystallization, due to its operational flexibility, the use of more or less selective extractants which otherwise expensive cost may be minimised by the use of special equipment, i.e. centrifugal contactors, etc.

Though the relationship between caesium and solvent extraction dates back to near 50 years, in recent times, calixarenes, and especially calixarenecrown ethers derivatives, have been extensively investigated for the extraction of this element.

Thus, calixarene-crown ethers, tailored framed to various configurations, i.e. cone, partial cone and 1,3-alternate, have been synthesised to extract caesium; and from these, 1,3 - alternate shows the best binding capacities for the element ${ }^{[45]}$.

Some authors describe ${ }^{[46 \text { and } 47]}$ the extraction of caesium by nitrobenzene solutions of several $\left(\mathrm{Na}^{+}\right.$, $\mathrm{K}^{+}, \mathrm{Rb}^{+}, \mathrm{H}^{+}$) dicarbollylcobaltates derivatives in the presence of polypropylene glycol (PPG425). In all the cases, CsL (L being PPG425) is formed in the organic phase, except for the $\mathrm{H}^{+}$-derivative in which both HL and CsL are present in the organic phase.

Sodium tetraphenylboron (TPB) in nitrobenzene has been used to extract ${ }^{137} \mathrm{Cs}$, from an aqueous radioactive laboratory waste, in the presence of high concentration of $\mathrm{Na}^{+[48]}$. At $\mathrm{pH}$ of $2,{ }^{137} \mathrm{Cs}$ binds with tetraphenylboron anion, being separated from the waste, then the element is stripped and concentrated from the loaded organic solution using $3 \mathrm{M} \mathrm{HNO}_{3}$ as strippant. 
Mohapatra has reported ${ }^{[49]}$ the extraction of caesium from a high level waste by calix[4]-bis-2, 3-naphtho-crown-6 (CNC) dissolved in a mixture of nitrobenzene and toluene. The process was investigated in a continuous basis by the use of four extraction and two stripping (distilled water) stages. The process yields $>99 \%$ caesium recovery with a remarkable selectivity over other fission products, though the extractant slightly losses its extractability characteristics after being in contact with the HLW for 10 days. On the other hand, nitrobenzene and toluene are not acceptable as diluents on a big scale due to environmental and safety restrictions (particularly in the EU and the USA), therefore they should be replaced by other diluents.

Besides calixarenes-crown ethers, there are other extractants used for $\mathrm{Cs}(\mathrm{I})$ extraction, including room temperature ionic liquids ${ }^{[50}$ and 51$]$, i.e. crown ethers containing seven or eight oxygen atoms. They potentially have good size compatibilities for caesium, whereas this element has a good ion pairing ability with chlorinated cobalt dicarbollide (CCD), being the most efficient extracted cation by this extractant.

Since the first CSEX (Caesium solvent extraction) to the now known as the Caustic-Side Solvent Extraction (CSSX) processes, a great progress has been outlined and carried out for separating caesium from alkaline high level wastes.

The CSSX process contains no less than 30 stages, sequentially 1 wash, 15 for extraction, 2 scrub, and 15 for stripping ${ }^{[52]}$. Originally, the organic phase has been constituted by three organic compounds, with a specific work to do, dissolved in Isopar L (aliphatic diluent): the extractant, actually calix[4]arene-bis(tert-octylbenzo-crown-6) (BOBCalixC6), a modifier 1-(2,2,3,3-tetrafluoropropoxy)-3-(4-sec-butylphenoxy)2-propanol (Cs-7SB) and finally a small amount of trioctylamine (TOA). While the modifier is needed to improve the extractant dissolution in the diluent, the presence of the amine overcomes related stripping problems of the process ${ }^{[53-56]}$.

Despite that CSSX process has shown its potential for HLW processing, various improvements have been developed and are worth mentioning here.

Though various calixarenes has been tested to replace BOBCalixC6, the latest development for caesium extraction is the so-called MaxCalix (monocrown calixcrown ether) extractant, which is more soluble in the diluent and this elevates the caesium distribution ratio with respect to that obtained with the original calixarene ${ }^{[57]}$. Also, TOA had been replaced by a guanidine derivative LIX 79 extractant, which originally was developed to extract gold(I) cyanide $^{[58]}$, whereas boric acid substitutes for nitric acid as strippant ${ }^{[59}$ and 60$]$.
These improvements has led to a promising Next-Generation CSSX process with improved decontamination factor and caesium concentration factor. In this new concept, the extraction-stripping process runs by means of 18 stages: 7 for extraction, 2 scrub, 7 for stripping and 2 wash stages ${ }^{[61]}$, a considerable reduction in the number of stages is achieved with respect to the original CSSX.

Other caesium extraction processes has been described in China, France, India, Russia and

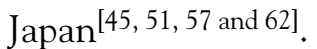

Finally to mention that nowadays processes for the co-extraction of both caesium and strontium are also continuously proposed ${ }^{[51]}$, being the tendency to consider that the concept of treating both elements as one sole product has many benefits ${ }^{[63]}$, against the alternative of treating each separately.

\section{METAL EXTRACTION FROM SECONDARY SOURCES}

In the era of sustainable development a great importance is attributed to recovery of raw materials from secondary sources. Pyrometallurgical methods (such as Umicore precious metal recovery process) ${ }^{[64]}$ are the most frequently used for metal winning from secondary sources, particularly from electric and electronic scrap and spent catalysts. However, the hydrometallurgical processes can compete with pyrometallurgical ones in the case of solutions of variable concentrations and small volumes. Among a number of developed hydrometallurgical processes of metal recovery from various secondary sources, some have been used in pilot plants. As an example, a plant for reprocessing spent batteries containing mercury and manganese was built in Spain in $1997^{[65}$ and 66$]$. It aimed at extractive concentration and purification of zinc solution produced by leaching of the batteries. The Modified Zincex Process (the same that is applied in Skorpion Zinc plant) developed by Técnicas Reunidas was proposed for zinc recovery from sulphate solution by extraction with DEHPA. The SX circuit included 3 extraction, 3 washing and 2 stripping stages. The target plant capacity was $2800 \mathrm{t} /$ year. Although the authors of the design gave weight to the flexibility in operation, very high quality of products and by-products, and easy operational control, after a few years the plant was closed. However, this experience has given chance to improve the technology that now is considered to be environmental friendly and attractive for secondary zinc recovery.

In Poland, a hydrometallurgical technology for purification of crude nickel sulphate (CNS) developed by KGHM Ecoren (part of the KGHM 
Polska Miedz Capital Group-the ninth-largest producer of copper and second-largest producer of silver in the world) in collaboration with the Institute of Nonferrous Metals was awarded in 2007 [67]. The project assumed that the plant for extractive purification of CNS and production of cobalt sulphate and nickel hydroxide (an alternative component of battery mass) would be constructed and operating till the year 2010. The production target amounted to $2200 \mathrm{t} /$ year of CNS being processed. It would be the first installation applying large-scale extraction in Poland ${ }^{[67}$ and 68$]$. Cyanex 272-an organic acid well known and used in the processes of $\mathrm{Ni} / \mathrm{Co}$ recovery was proposed as an extractant ${ }^{[69]}$. High efficiency of the purification process and an effective recovery of cobalt should be emphasized as advantages of the extractant. The project assumed the processing of the CNS solution containing: $62 \mathrm{~g} / \mathrm{dm}^{3} \mathrm{Ni}(\mathrm{II})$, $190 \mathrm{mg} / \mathrm{dm}^{3} \mathrm{Zn}$ (II), $340 \mathrm{mg} / \mathrm{dm}^{3} \mathrm{Cu}(\mathrm{II}), 930 \mathrm{mg} / \mathrm{dm}^{3}$ $\mathrm{Co}(\mathrm{II})^{[69]}$. The first step involves Ni purification from other cationic impurities by extraction of zinc, copper and cobalt.

Hexahydrate nickel sulphate- $\mathrm{NiSO}_{4} \cdot 6 \mathrm{H}_{2} \mathrm{O}$ can be produced as a result of evaporation and crystallization of the raffinate. In the second step, the so called collective concentrate of metal sulphates containing mainly cobalt with additives of zinc, copper and nickel and formed as a by-product in the first stage of extraction, is proceeded to extract cobalt. The advantages of extraction compared to pyrometallurgical processes are as follows: higher intensity of the process, smaller volume of the equipment applied (lower investment costs).

However, it seems that the project of the extraction plant for SSN purification encountered difficulties because so far, till the end of 2012, the installation does not work. In the case of processing of metals from secondary sources, pyrometallurgical processes are still more attractive, proven by the number of high temperature installations belonging to large companies (e.g. Umicore).

Nevertheless, pyrometallugical processes have noticed unfavourable trends in recent years because of high energy costs and tighter environmental regulations concerning stringent air quality standards. As an example of changes in the attitude to pyrometallurgy a conversion of old smelter technology in Monaca plant (Horsehead Corporation) into Modified Zincex Process can be given. Till the end of 2013 Horsehead Corp. plans to produce 155000 t Zn/year from Waelz oxide (after recycling of electric arc furnace dust) and galvanizer skimmings using SX-EW technology ${ }^{[41}$ and 70$]$. As over one third of world zinc origins from secondary materials, and dust waste from EAFs generated annually amounts to $6 \mathrm{mln}$ tons, it becomes an important source of zinc for the galvanizing industry that uses nearly half of total global zinc demand.

Secondary zinc oxides are becoming an important feedstock for zinc production and replace zinc sulphide concentrates, particularly in Europe and Japan, because of less expensive recycled zinc, no sulphur content in zinc secondary materials, consumption of acid instead of generation excessive one, reduction in the cost of iron removal and disposal, greater feed diversity and less sensitivity to fluctuations in the concentrate market, lower energy consumption than sulphide concentrates ${ }^{[70]}$.

The new plant (Fig. 8) will replace a high-cost electrothermic process by the technology considered as more environmental friendly because of lower energy consumption, higher labour productivity, significantly less fossil fuel usage. Additionally, the new installation will produce Special High Grade and Continuous Galvanizing Grade zinc apart from the Prime Western Grade produced currently by smelter. Moreover, another advantage of SX-EW application in this plant is recovery of silver and lead in PLINT process ${ }^{\text {[71 and } 72]}$. Another zinc plant from Waelz oxide based on MZP Zinc recovery operates in Japan (Akita Zinc Plant) and produces $200000 \mathrm{t} /$ year $^{[41,70}$ and 73$]$.

Recently, a process for the recovery of indium from LCD screen wastes has been described ${ }^{[74]}$. The indium contained in the solid waste is dissolved either by sulphuric, hydrochloric or nitric acids, though dissolution by the latter requires a longer processing time. In any case, sulphuric acid is chosen as the most suitable dissolution medium as it is less corrosive than $\mathrm{HCl}$ solutions. From the pregnant solution (typically $0.74 \mathrm{~g} / \mathrm{dm}^{3}$ In, $0.03 \mathrm{~g} / \mathrm{dm}^{3}$ Sn and $1 \mathrm{M}$ sulphuric acid) $20 \%$ D2EHPA in Shellsol 2046 is used as an organic phase to extract the metal ions in two stages at A/O ratio of 8 , the loaded organic solution $\left(6.2 \mathrm{~g} / \mathrm{dm}^{3} \mathrm{In}\right.$, $\left.0.4 \mathrm{~g} / \mathrm{dm}^{3} \mathrm{Sn}\right)$ is stripped also in two stages at a $\mathrm{O} / \mathrm{A}$ ratio of 2 using $1.5 \mathrm{M} \mathrm{HCl}$ solution. The unloaded organic solution is recycled to extraction, whereas from the strip solution containing $12.2 \mathrm{~g} / \mathrm{dm}^{3}$ In and $0.02 \mathrm{~g} / \mathrm{dm}^{3}$ tin, indium may be recovered by cementation.

\section{IONIC LIQUIDS IN EXTRACTION}

Laboratory studies on extraction of metal ions can be divided into several directions: the search for and synthesis of new extractants (e.g. macrocyclic or bifunctional extractants ${ }^{[75-77]}$, elimination of volatile organic compounds (e.g. the use of aqueous biphasic systems-ABS ${ }^{[78-80]}$, search for applications for ILs in extraction systems ${ }^{[3 \text { and } 81-100]}$. 


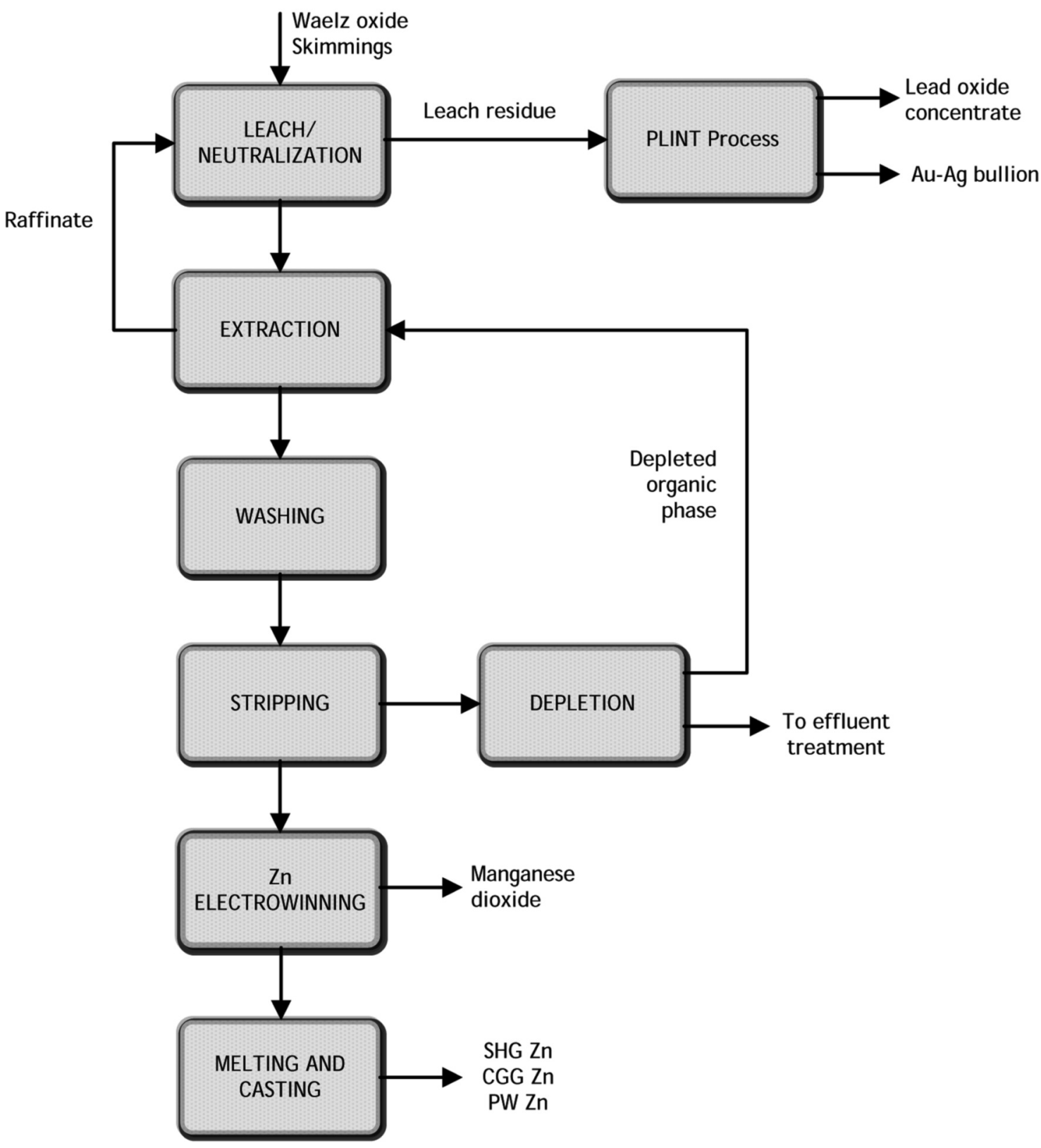

Figure 8. Simplified schematic representation of the new Horsehead plant for secondary zinc processing ${ }^{[41]}$.

\section{Figura 8. Representación simplificada de la nueva planta Horsehead para el procesado de zinc secundario ${ }^{[41]}$.}

In the last decade a rapid development of methods for the synthesis of ionic liquids and their applications has been noticed. Currently, there are few areas that are not trying to use the ILs ${ }^{[101-106]}$. Ionic liquids cover compounds of various hydrophilic-lipophilic properties, depending on the size of the hydrophilic and hydrophobic groups, the presence of perfluorinated groups, and the nature of the counterion. Ionic liquids (IL) are defined as salts that are liquid at temperatures below $100^{\circ} \mathrm{C}$. Their specific features, such as non-measurable volatility, non-flammability, thermal stability, wide electrochemical window decide about increasing interest in application of various ILs $^{[104}$ and 108$]$. Additionally, they can be easily tuned and designed for particular applications (e.g. task specific ILs) ${ }^{[89]}$. Chemically, the ionic liquids are quaternary ammonium, imidazolium, phosphonium salts of low solubility in water. Therefore, ILs easily form a separate phase that is capable to solubilize ionic species. Moreover, ionic liquids may form, together with other conventional metal extractants synergistic mixtures. Although the industrial 
importance of ionic liquids in the extraction systems is low, intensive research makes ILs become more and more interesting for application for separation processes. To date, there have been many reports on the use of imidazolium ionic liquids as solvents in extraction of various metal ions; a 3D view of an imidazolium salt derivative is shown in figure 9.

Quaternary imidazolium salts are most commonly used in extraction as additives to conventional systems. Their presence increases efficiency and selectivity of extraction compared with conventional organic solvents, and additionally reduces volatility of the organic phase. However, there is a problem of metal ion stripping from the loaded IL phase, especially when the ionic liquid and metal ion form a strongly bound ion pair. The effectiveness of removal of many metal ions (e.g. $\mathrm{Ag}(\mathrm{I}), \mathrm{Ce}(\mathrm{III})$, $\mathrm{Eu}(\mathrm{III}), \mathrm{Y}(\mathrm{III}), \mathrm{Cs}(\mathrm{II}), \mathrm{Sr}(\mathrm{II}))$ has been proven as a result of replacement of the traditional solvents such as chloroform, dodecane in pyridinecalix-4-arene ${ }^{[81]}$ or in CMPO (octyl(phenyl)-N,N-diisobutylcarbamoylmethylphosphine oxide) ${ }^{[82]}$ by 1 -alkyl3-methylimidazolium hexafluorophosphate, and in crown ether $18 \mathrm{C} 6^{\text {[83 }}$ and ${ }^{84]}$ by 1 -methyl-3pentylimidazolium bis (trifluoromethylsulphonyl) imide. The use of ionic liquids as replacement for diluents in the extraction of rare earths has been described elsewhere ${ }^{[85]}$. 2-ethylhexyl phosphonic acid mono-(2-ethylhexyl) ester (HEHEHP) is used as an extraction agent whereas the ionic liquid 1-octyl-3-methylimidazolium hexafluorophosphate (C8-mimPF6) acts as a diluent for the system. The established extraction order is as follows: $\mathrm{Lu}>\mathrm{Yb}>\mathrm{Tm}>\mathrm{Er}>=\mathrm{Y}=\mathrm{Ho}>\mathrm{Dy}>\mathrm{Tb}>\mathrm{Gd}>\mathrm{Eu}>\mathrm{Sm}>$ $\mathrm{Nd}>\mathrm{Pr}>\mathrm{La}>\mathrm{Ce}$ (all the elements at their +3 state), with $\mathrm{pH}_{50}$ (equilibrium $\mathrm{pH}$ value at which the distribution coefficient equals to 1 ) ranging from near 0.8 for $\mathrm{Lu}(\mathrm{III})$ to 2.5 for $\mathrm{Ce}(\mathrm{III})$.

The extractants such as N,N,N',N'-tetrabutyl-3oxapentanediamide (TBDA) and N,N'-dimethyl-N, N'-dibutyl-3-oxapentanediamide (MBDA) or $\mathrm{N}, \mathrm{N}, \mathrm{N}^{\prime}, \mathrm{N}^{\prime}$-tetra-n-octyl diglycolamide (TODGA) used to extract $\mathrm{Th}(\mathrm{IV})^{[86]}$ or $\mathrm{Am}(\mathrm{III}), \mathrm{Pu}(\mathrm{IV})$ and $\mathrm{UO}_{2}{ }^{2+[87]}$ have been dissolved in various imidazolium derivatives. As one can expect, the extraction systems using the ILs are more efficient for all the above actinides if compared with traditional diluents in the extraction system (e.g. dodecane or chloroform). The extraction of these actinides proceeds according to a cation exchange mechanism.

Also the use of D2EHPA or bis(2-ethylhexyl) diglycolamic acid (HDEHDGA) extractants diluted in the ionic liquid 1-octyl-3-methylimidazolium bis(trifluoromethanesulphonyl)imide (omimNTf2) for the extraction of ${ }^{(152+154)} \mathrm{Eu}\left(\right.$ III) and ${ }^{241} \mathrm{Am}$ (III) is

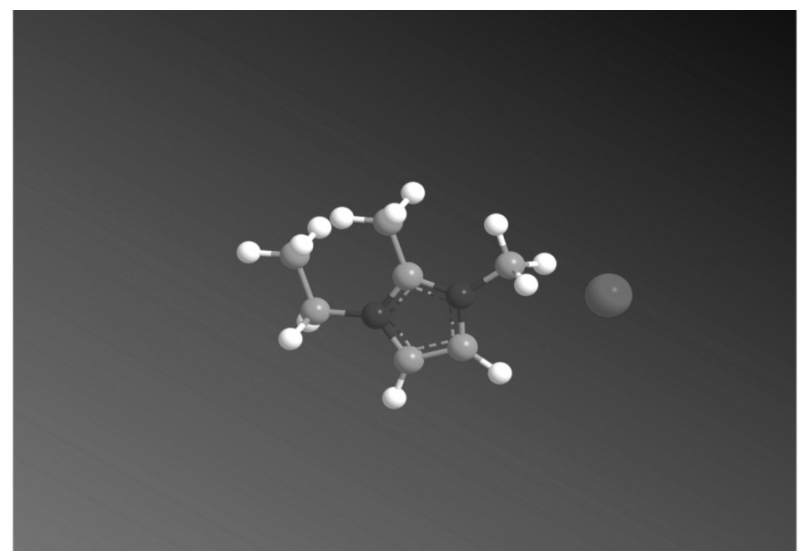

Figure 9. 1,2,3-substituted imidazolium salt. Orange: carbon. White: hydrogen. Blue: nitrogen. Pink: anion. See front cover for colours key.

Figura 9. Sal de imidazolio 1,2,3-sustituida. Naranja: carbono. Blanco: hidrógeno. Azul: nitrógeno. Rosa: anion. Mirar la cubierta para identificación de colores.

described ${ }^{[109]}$. The results are concluded with the feasibility of separating lanthanides from actinides present in high-level liquid wastes. However, the separation of these two elements is also possible by the use of tri-n-octylmethylammonium bis (2-ethylhexyl) phosphate and tri-n-octylmethylammonium bis (2-ethylhexyl) diglycolamate ionic liquids diluted in conventional diluents ${ }^{[110]}, \mathrm{Am}$ (III) can be extracted from acidic solutions by the use of TODGA and a variety of ionic liquids ([C4mim][PF6], [C6mim][PF6] and $[\mathrm{C} 8 \mathrm{mim}][\mathrm{PF} 6]$. Moreover, the system selectively separates americium from uranium and plutonium ${ }^{[111]}$.

Not only has been investigated the effect of ionic liquids as replacement for the diluents in actinides processing, but also the extraction behaviour of mercury(II) and cadmium(II) is described when 1-butyl-3-methylimidazolium hexafluorophosphate ([Bmim]PF6]) is used as diluent for 8-hydoxyquinoline ${ }^{[88]}$. Both elements are extracted as neutral $\mathrm{HgR}_{2}$ and $\mathrm{CdR}_{2}$ species ( $\mathrm{R}$ being the active group of the oxime) within more than $98 \%$ efficiency and recovered using moderate low (0.25-1 M) concentrations of nitric acid. It is also described, that the ionic liquid does not appreciably extract (less than $5 \%$ ) both base metals.

Another precious metal of interest is rhodium, being the potential of ammonium ILs (e.g. $\left.\left[\left(\mathrm{CH}_{3}\right)_{3} \mathrm{NCH}_{2} \mathrm{CH}_{2} \mathrm{OMe}\right]\left[\mathrm{Tf}_{2} \mathrm{~N}\right]\right)$ and $\mathrm{CMPO}$ or TODGA extraction systems in the recovery of $\mathrm{Rh}(\mathrm{III})$ from spent nuclear fuel recently described ${ }^{[112]}$.

Some ionic liquid extraction systems operate very efficiently without a ligand complexing metal ions. Successful attempts to use imidazolium and 
ammonium ILs as sole extractants for zinc, cadmium, copper and $\mathrm{Fe}(\mathrm{III})^{[113 \text { and } 114]}$ or $\mathrm{Ni}, \mathrm{Co}^{[115]}$ from $\mathrm{HCl}$ solutions have been made. Several Aliquat 336 (methyltrioctylammonium chloride) [A336][Cl] derived ILs have been already described in literature, and its efficient extraction behaviour as different ILs is in agreement with numerous previous studies on [A336][Cl] solutions in typical VOCs ${ }^{[116-118]}$. Some of them can be applied for separation of metal ions, such as $\mathrm{Pd}^{[119]}, \mathrm{UO}_{2}{ }^{2+}{ }^{[120]}$, cadmium from natural river matrix ${ }^{[19]}, \mathrm{Eu}^{[122]}, \mathrm{REE}^{[123]}$ or $\mathrm{Pt}^{[124]}$. [A336][Cl] is also an effective carrier for extraction $\mathrm{n}$ membrane systems, so called non-dispersive solvent extraction (NDSX) or emulsion pertraction (PERT). It has been used for chromium(VI) removal from ground waters $^{[125]}$. Other ammonium ILs, such as sulphate of Primene 81R, Primene TOA, Amberlite LA2 and tridodecylamine, has been investigated in pseudoemulsion based hollow fiber strip dispersion (PEHFSD) for extraction of iron(III) from sulphuric acid solutions ${ }^{[126]}$. The most efficient for iron(III) transport using PEHFSD is Primene JMT based IL. Recently Primene JMT has been used for preparation Primene JMT-Cyanex 272 ionic liquid for liquid-liquid extraction and separation of $\mathrm{Co}(\mathrm{II})$ and $\mathrm{Ni}$ (II) (more than $99 \%$ Co and about $10 \% \mathrm{Ni}$ in the extract) from neutral chloride solutions ${ }^{[115]}$. The best separation of $\mathrm{Co}$ (II) from $\mathrm{Ni}$ (II) has been obtained for the organic phase containing $10 \%$ Cyanex $272+10 \%$ JMT in aliphatic hydrocarbon Exxsol D100. The presence of the amine is advantageous because enables to control the $\mathrm{pH}$ of the equilibrated aqueous phases during metal ion extraction without acid neutralization between successive steps of extraction (which is necessary when only acidic extractant is used).

Recently also phosphonium ionic liquids has been reported to be used in extraction systems, as well as for the separation of metal ions as active carriers immobilized at adsorbents. Phosphonium ionic liquids are more stable at high temperatures than the most common imidazolium ILs. Furthermore, phosphonium cation strongly disturbs the electrostatic interactions between cations and anions of IL. Thus, the anion of phosphonium IL participates in extraction easier than that coming from imidazolium or ammonium salt because smaller cation containing nitrogen $(\mathrm{N})$ strongly interacts with anions ${ }^{[127]}$.

These features influence growing interest in application of phosphonium ILs as metal ion carriers in SX. Lanthanum chloride extraction from solutions of $\mathrm{HCl}$ with mixtures of neutral organophosphorous compounds and such ILs as butyldiphenylphosphonium hexaflurorphosphate or bis(trifluoromethylsulphonyl) imide should be mentioned as an example of the use of phosphonium ILs in the separation processes ${ }^{[128]}$. An efficient extraction of $\mathrm{Fe}(\mathrm{III})$ from $6 \mathrm{M} \mathrm{HCl}$ with trihexyl(tetradecyl)phosphonium chloride (Cyphos IL 101 - Table V) diluted with chloroform has been proven by Kogelnig et al. ${ }^{[129]}$. Moreover, nickel is not extracted, and therefore selective separation of $\mathrm{Fe}$ (III) from $\mathrm{Ni}$ (II) is possible. Cyphos IL 101 has been also used for the impregnation of Amberlite XAD-7 beds and biopolymer capsules in order to effectively remove $\mathrm{Zn}(\mathrm{II}), \mathrm{Hg}(\mathrm{II}), \mathrm{Au}(\mathrm{III})$ from $\mathrm{HCl}$ solution ${ }^{[130-132]}$.

Looking for new and more efficient extraction systems than those used previously, the author has carried out some studies on the extraction of various metal ions (Zn, $\mathrm{Fe}(\mathrm{II}), \mathrm{Fe}(\mathrm{III}), \mathrm{Pd}, \mathrm{Pt}, \mathrm{Co}, \mathrm{Ni}$ ) from chloride solutions with selected phosphonium ILs in toluene. Some Cyphos commercial phosphonium ILs studied in separation processes are presented in table $\mathrm{V}$.

The laboratory studies have shown that the quaternary phosphonium salts can be used as extractants of zinc(II) from chloride solutions. Cyphos IL 101 and IL 104 in toluene are very effective extractants of zinc(II) and make possible $100 \%$ extraction of the metal ions ${ }^{[95]}$. In comparison, Cyphos IL 109 in toluene extracts only about $15 \%$ of zinc(II) and is not efficient. The influence of the IL anion on the extraction properties of such quaternary phosphonium salts has been indicated. $\mathrm{Zn}$ extraction decreases in the following series of anions: $\mathrm{Cl}^{-}=$bis (2,4,4-trimethylpentyl)phosphinate> $\mathrm{BF}_{4}->\mathrm{NTf}_{2}$ - (bis (trifluoromethylsulpho-nyl) imide) and corresponds to the increasing hydrophobicity of the ILs. The extraction of metal ions with Cyphos IL 101 increases in the following series: $\mathrm{Fe}(\mathrm{II})<\mathrm{Zn}<\mathrm{Fe}$ (III). Selective extraction of zinc in the presence of Fe(II) with Cyphos IL 101 is possible only from solutions of high content of zinc, but the problem is still involved in the effective stripping of the metal ions from the organic phase ${ }^{[96]}$. Some of these phosphonium salts has been investigated in the extraction of $\mathrm{Co}(\mathrm{II})$ and $\mathrm{Ni}$ (II) from chloride solutions ${ }^{[97]}$. The extraction of $\mathrm{Co}(\mathrm{II})$ by Cyphos IL101 is $\mathrm{HCl}$ concentration dependant, whereas this element can be extracted from aqueous feed without $\mathrm{HCl}$ using Cyphos IL104. Different extraction mechanisms are responsible for such behaviour, and the successful separation of $\mathrm{Co}$ (II) from $\mathrm{Ni}(\mathrm{II})$ is achieved with Cyphos IL104.

Quaternary ammonium and phosphonium ionic liquids are successfully used for the removal of copper, nickel and zinc from activated sewage sludge ${ }^{[98]}$. It is claimed that this SX procedure is more successful than conventional methods such as incineration, acid extraction, thermal treatment, etc., in the removal of heavy metals from activated sludge.

The extraction of $\mathrm{Pd}(\mathrm{II})$ and $\mathrm{Pt}(\mathrm{IV})$ these two precious metals has been also investigated using Cyphos IL 101 and IL $104^{[92}$ and 94$]$ or mixtures of 
Table V. Commercial name, active substance and structures of phosphonium ILs applied for metal ion extraction

Tabla V. Nombre comercial, grupo activo y estructuras de líquidos iónicos con base fosfonio utilizados en la extracción de metales

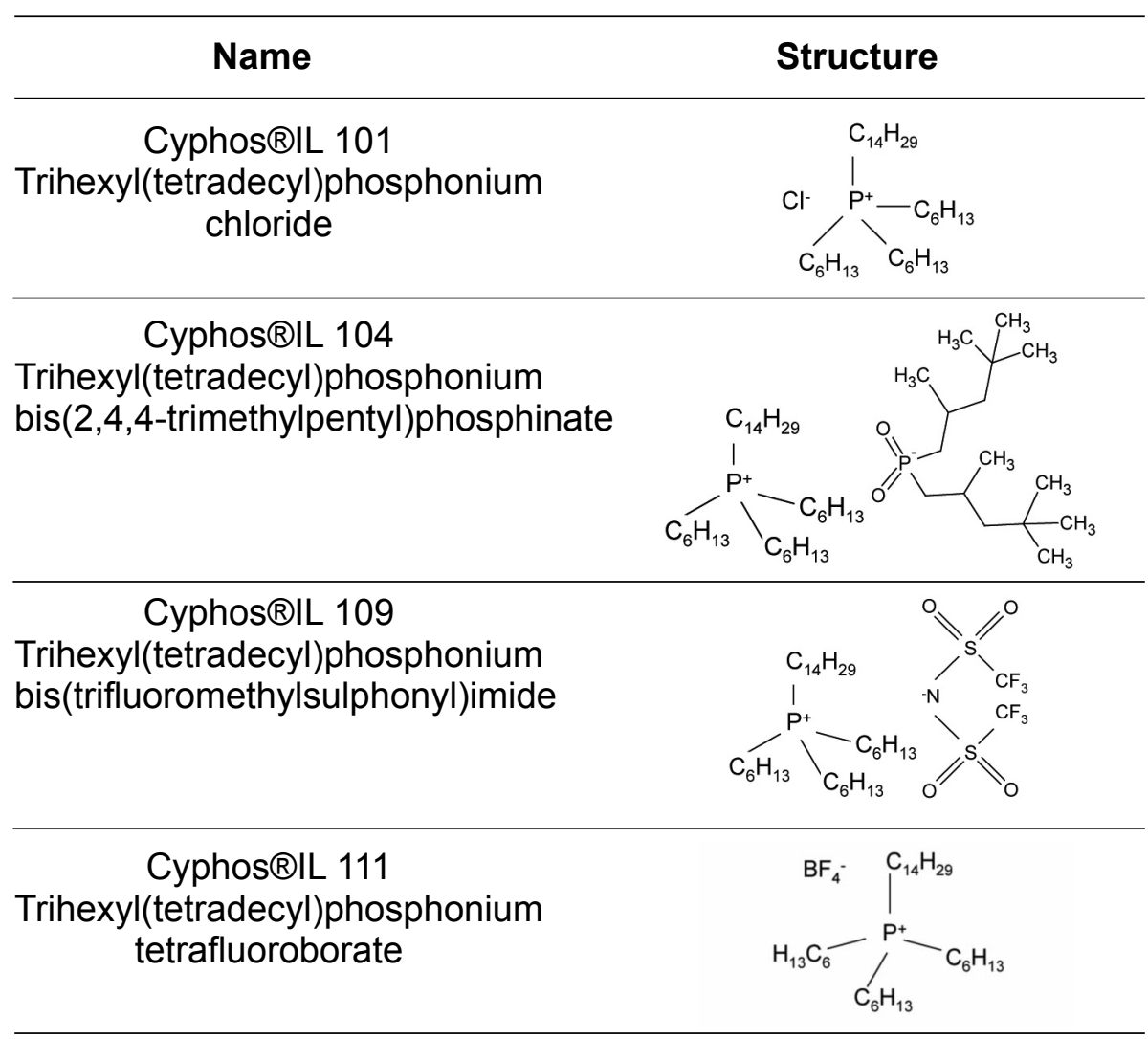

trioctylammonium is(trifluoromethanesulfonyl)amide and trioctylammonium nitrate ${ }^{[133]}$. Either $\mathrm{Pd}(\mathrm{II})$ and $\mathrm{Pt}(\mathrm{IV})$ are extracted almost quantitatively from 0.1-3 $\mathrm{M}$ hydrochloric acid solutions, whereas a number of base metals and $\mathrm{Ru}(\mathrm{III})$ and $\mathrm{Rh}$ (III) were only slightly extracted. Almost $100 \%$ of palladium is efficiently extracted from $0.1 \mathrm{M} \mathrm{HCl}$ using Cyphos IL 101, in the presence of ions such as $\mathrm{Ni}$, $\mathrm{Cu}, \mathrm{Pb}, \mathrm{Fe}(\mathrm{III}), \mathrm{Rh}$ and $\mathrm{Ru}$, while only $12 \%$ of the other metal is transported into the organic phase. Separation of palladium from platinum is not as effective $(70 \% \mathrm{Pd} \text { and } 65 \% \mathrm{Pt})^{[93]}$. Increase in $\mathrm{HCl}$ concentration in the aqueous phase has a negative effect on the efficiency of palladium extraction with phosphonium ILs, while stripping takes place preferably with $0.5 \mathrm{M} \mathrm{NH}_{4} \mathrm{OH}$. Both elements can be stripped from ammonium ILs by the use of nitric acid solutions, being platinum selectively stripped from palladium by controlling the concentration of nitric acid in the strip solution.

A number of ionic liquids containing pyridinium, pyrrolidinium and piperidinium cations with anion bis(trifluoromethylsulfonyl)imide has been investigated in the extraction of silver, palladium and gold $^{[134]}$, and whereas ionic liquids containing a disulfide or a nitrile groups are good extractants for silver and palladium, all the investigated ionic liquids are very efficient and selective for gold extraction.

Cyphos IL 101 has been also used as a potential extractant for cadmium (metal ion considered as highly toxic, and thus essential for being removed from liquid effluents) present in hydrochloric acid solutions ${ }^{[135]}$. Under acidic conditions $(0.1-1 \mathrm{M} \mathrm{HCl})$ the metal is almost quantitatively extracted at $1 \mathrm{~g} / \mathrm{dm}^{3}$ $\mathrm{Cd}(\mathrm{II})$ initial concentration and using $2.5-10 \% \mathrm{v} / \mathrm{v}$ Cyphos IL101 solutions in cumene; if the metal concentration decreased to $0.1 \mathrm{~g} / \mathrm{dm}^{3}$, the extent of extractant concentrations to be effective for cadmium removal can be as low as $1 \% \mathrm{v} / \mathrm{v}$ in cumene. The metal is efficiently stripped from the loaded organic solutions only using ammonium hydroxide solutions.

A continuous SX process for the recovery of rare earths contained in a simulated fluorescent powder had been recently developed ${ }^{[86]}$. In this investigation, the bifunctional ionic liquids, derived from the quaternary ammonium salt Aliquat 336, [A336][P204] 
and [A336][P507] have been used to extract these elements in a high concentration of aluminium nitrate. It is described that both reagents have similar characteristics that neutral organophosphorous extractants. Rare earths can be extracted with recoveries of near $95 \%$ using $5-7$ stages at a $\mathrm{pH}$ of 0.56 and $\mathrm{V}_{\text {org }} / \mathrm{V}_{\text {aq }}$ ratio of 4 .

\section{CONCLUSIONS}

- Contemporary directions of the development of metal ion industrial extraction include processing of waste effluents, ores of complex or unconventional composition and low metal content, or secondary resources, and are focused mainly on modification and improvement of the existing technologies. At the same time laboratory researches support the development of industrial technologies by the investigation and explanation of the disadvantageous phenomena that occur during extraction, the search for new extractants and solutions for the separation processes. In this paper, only some examples of extraction development directions are presented, consciously not describing the extraction techniques in analytical chemistry, or combining extraction with membrane techniques such as: non-dispersive membrane-based solvent extraction or membranebased extraction with strip/organic dispersion, as they were recently reviewed ${ }^{[108,136}$ and 137$]$.

- The variety of solutions, needs and separation systems make the extraction of metal ions still face new challenges. Some of the challenges include acquiring the metals and by-products so far not recovered, the production of highly pure metals, increasing the amount of waste streams to be treated and recovered, adaptation to increasingly stringent environmental requirements, and reduction of operating costs by improving the existing technologies, improving the extraction kinetics and designing new devices.

- There are attempts to use liquid-liquid extraction for metal ion separation from secondary sources on a small scale. However, up to now the most successful are big industrial plants producing such valuable metals as copper, nickel, cobalt from primary sources. In the case of the treatment of spent fuel wastes, it seems that recent trends aim for the co-extraction of both caesium and strontium.

- For the time being, an interest for the use of ionic liquids as extractants for metal ions has been increasing, particularly due to chance for elimination of organic diluents from some extraction systems, and the improvement of separation efficiency. However, metal ion extraction with ILs has not yet any practical application but laboratory scale research.

\section{Acknowledgements}

The work was founded by 32/067/2013 DS-PB grant. Also, the authors thank for support the CSIC (Spain). Authors thanked to L.F. Alvarez and F. Morcillo their continuous efforts in editing the present manuscript.

\section{REFERENCES}

[1] G.M. Ritcey, Tsinghua Sci. Technol. 11 (2006) 137-152.

[2] J. Szymanowski, Selected physicochemical aspects of metal ion removal, Monographic and specialist lectures "Membranes Theory and Practice", Ed. R. Wódzki, Nicolaus Copernicus University, Toru, Poland, 2003, pp. 30-46.

[3] M. Regel-Rosocka and M. Wiśniewski, Applications of ionic liquids in science and technology. Ed. S.T. Handy, INTECH, Croatia, 2011, pp. 375-398.

[4] K.G. Fisher, Proc. 6th Southern African Base Metals Conference, The Southern African Institute of Mining and Metallurgy, 2011, pp. 237-257.

[5] G.A. Kordosky, SAIMM November/December (2002) 445-450.

[6] L. Kolver, Camec to build multimillion-dollar SX plant in DRC, Base Metals, online access: http://www.miningweekly.com/article/camec-tobuild-multimilliondollar-sx-plant-in-drc-200807-25 (27.06.2013).

[7] J. Chadwick, International Mining (2008) 8-16.

[8] http://www.shalinaresources.com/cusx-ewplant.aspx (28.06.2013).

[9] http://www.centralasiametals.com/projects/ kounrad/ (28.06.2013)

[10] R. Hernández, F. Pino, J. Roco, P. Amigo, P. E. Thompsen and M. Ferrera, Proc. XIXth International Solvent Extraction Conference, ISEC 2011, Eds. F.L. Valenzuela, B.A. Moyer, Gecamin, Santiago de Chile, Chile, 2011, p. 20.

[11] http://www.mining-technology.com/projects/ boleoproject/ (02.07.2013).

[12] C.Y. Cheng, Hydrometallurgy 84 (2006) 109-117.

[13] D. Dreisinger, J. South African Inst. Mining Metall. 109 (2009) 253-271.

[14] D. Dreisinger, T. Glück, K. Marte, R. Hamm, R. Molnar, J. Lu and F. Xie, Proc. Lead-Zinc 
Symposium, Eds. A. Siegmund, L. Centomo, C. Ginnen, N. Piret, G. Richards and R. Stephens, TMS, Wiley Eds., 2010, pp. 623636.

[15] D. Dreisinger, F. Xie, T. Glück and K. Marte, Proc. International Solvent Extraction Conference, ISEC 2011, Eds. F.L. Valenzuela and B.A. Moyer, Gecamin, Santiago de Chile, 2011, p. 22.

[16] D. Dreisinger, F. Xie, T. Glück and K. Marte, Proc. International Solvent Extraction Conference, ISEC 2011, Eds. F.L. Valenzuela and B.A. Moyer, Gecamin, Santiago de Chile, 2011, p. 27.

[17] C. Fleming, SGS Minerals Services, Technical Bulletin 01 (2002) 1-5.

[18] D. Dreisinger, W. Murray, D. Hunter, K. Baxter, M. Wardell-Johnson, A. Langley, J. Liddicoat, C. Fleming, J. Ferron, A. Mezei, J. Brown, R. Molnar and D. Imeson, SGS Minerals Services, Technical Bulletin 06 (2006) 1-13.

[19] C.J. Ferron, C.A. Fleming, P.T. O'Kane and D. Dreisinger, SME Annual Meeting and Exhibit, February 26-28, Denver, Colorado, 2001, pp. 1-9.

[20] I. Mihaylov, E. Krause, D.F. Colton, Y. Okita, J.P. Duterque and J.J. Perraud, CIM Bull. 93 (2000) 124-130.

[21] G. Bacon and I. Mihaylov, SAIMM November/ December (2002) 435-444.

[22] M.G. King, JOM (2005) 35-39.

[23] K.R. Barnard, Hydrometallurgy 103 (2010) 190-195.

[24] P.M. Cole and A.M. Feather, Proc. International Solvent Extraction Conference, ISEC 2008, Ed. B.A. Moyer, Tucson, Arizona, EE.UU., 2008, pp. 131-136.

[25] P.M. Cole and K.C. Sole, Miner. Process. Extr. Metall. Rev. 24 (2003) 91-137.

[26] http://www.skorpionzinc.com.na/index.php?/ About-Skorpion/operatiions.html (06.02.2012).

[27] H. Fuls, K.C. Sole and T. Bachmann, Proc. International Solvent Extraction Conference, ISEC 2005, Beijing, China, 2005, pp. 1223. 1228.

[28] J. Gnoinski, Skorpion Zinc: optimisation and innovation, Proc. 4th Southern African Conference on Base Metals, Namibia, 2007, pp. 329-342.

[29] J. Gnoinski, K.C. Sole, D.R. Swart, R.F. Maluleke, G.N. Díaz and F. Sánchez, Proc. International Solvent Extraction Conference, ISEC 2008, Ed. B.A. Moyer, Tucson, Arizona, EE.UU., 2008, pp. 201-207.

[30] J.M. Musadaidzwa and E.I. Tshiningayamwe, J. South African Inst. Mining Metall. 109 (2009) 691-695.

[31] R.W.A. Crowe, The Skorpion Zinc project,
Southern Namibia, Report No. 119.2000, Perth 2000.

[32] C. David, S. Engelbrecht, G.N. Díaz, F.R. Sánchez, A. Belen Mejias, Proc. International Solvent Extraction Conference, ISEC 2011, Eds. F.L. Valenzuela and B.A. Moyer, Gecamin, Santiago de Chile, 2011, p. 30.

[33] K.R. Barnard and M.N. Tsuntsaeva, Solvent Extr. Ion Exch. 30 (2012) 566-578.

[34] R. Halford and K.R. Barnard, Proc. International Solvent Extraction Conference, ISEC 2011, Eds. F.L. Valenzuela and B.A. Moyer, Gecamin, Santiago de Chile, 2011, p. 16.

[35] K.R. Barnard, Proc. International Solvent Extraction Conference, ISEC 2011, Eds. F.L. Valenzuela and B.A. Moyer, Gecamin, Santiago de Chile, 2011, p. 162.

[36] G. Cote, Solvent Extr. Ion Exch. 18 (2000) 703 727.

[37] J. Hakkarainen, A. Villarroel, A. Sotomayor, C. Rodríguez and R. Dellarossa, Proc. International Solvent Extraction Conference, ISEC 2011, Eds. F.L. Valenzuela and B.A. Moyer, Gecamin, Santiago de Chile, 2011, p. 19.

[38] H. Hein and P. Joly, Proc. XIXth International Solvent Extraction Conference, ISEC 2011, Eds. F.L. Valenzuela and B.A. Moyer, Gecamin, Santiago de Chile, Chile, 2011, p. 8.

[39] W.A. Rickelton, A.J. Robertson and J.H. Hillhouse, Solvent Extr. Ion Exch. 9 (1991) 73-84.

[40] Bateman project profile, Inco's Goro Nickel solvent-extraction plant, accessible online at: http://www.bateman-litwin.com/files/ bateman/download/151120053513332.pdf (13.05.2013).

[41] Horsehead Holding Corp., Investor Presentation, August 2012, available online at: www.horsehead.net/downloadAttachmentNDO .pdf (24.06.2013).

[42] G.N. Díaz, D. Martín, F.R. Sánchez and S. Sanguilinda, Proc. International Solvent Extraction Conference, ISEC 2011, Eds. F.L. Valenzuela and B.A. Moyer, Gecamin, Santiago de Chile, 2011, p. 17.

[43] E. Alberts and C. Dorfling, Proc. International Solvent Extraction Conference, ISEC 2011, Eds. F.L. Valenzuela and B.A. Moyer, Gecamin, Santiago de Chile, Chile, 2011, p. 37.

[44] W. Weiwei, W. Xianglan, M. Shulan, L. Hongfei and L. Dequian, J. Rare Earths 24 (2006) 685-689.

[45] J.F. Dozol and R. Ludwig, Extraction of radioactive elements by calixarenes, in: Ion Exchange and Solvent Extraction, Vol.19, Ed. B.A. Moyer, CRC Press, Boca Raton, F.L., 2010, pp. 195-318. 
[46] E. Makrlik, P. Vañura and P. Selucky, $J$. Radioanal. Nucl. Chem. 287 (2011) 981-985.

[47] E. Makrlik, P. Vañura and P. Selucky, J. Radioanal. Nucl. Chem. 288 (2011) 429-233.

[48] A. Dash, R. Ram, Y.A. Pamale, A.S. Deodhar and M. Venkatesh, Sep. Sci. Technol. 47 (2012) 81-88.

[49] P.K. Mohapatra, P.S. Dhami, S. Panja, P. Jagasia, S.C. Tripathi, P.K. Dey and V.K. Manchanda, Desalin. Water Treat. 38 (2012) 59-64.

[50] P.R. Vasudeva Rao, K.A. Venkatesan, A. Rout, T.G. Srinivasan and K. Nagarajan, Sep. Sci. Technol. 47 (2012) 204-222.

[51] C. Xu, J. Wang and J. Chen, Solvent Extr. Ion Exch. 30 (2012) 623-650.

[52] R.A. Leonard, S.B. Aase, H.A. Arafat, C. Conner, D.B. Chamberlain, J.R. Falkenberg, M.C. Regalbuto and G.F. Vandegrift, Solvent Extr. Ion Exch. 21 (2003) 505-526.

[53] P.V. Bonnesen, L.H. Delmau, B.A. Moyer and R.A. Leonard, Solvent Extr. Ion Exch. 21 (2003) 141-170.

[54] L.H. Delmau, P.V. Bonnesen and B.A. Moyer, Hydrometallurgy 72 (2004) 9-19.

[55] L.H. Delmau, T.J. Lefranc, P.V. Bonnesen, J.C. Bryan, D.J. Presley and B.A. Moyer, Solvent Extr. Ion Exch. 23 (2005) 23-57.

[56] K.L. Swancutt, T.D. Cullen, S.P. Mezyk, G. Elias, W.F. Bauer, R.D. Ball, D.R. Peterman, C.L. Riddle, B.J. Mincher and J.J. Muller, Solvent Extr. Ion Exch. 29 (2011) 106-127.

[57] B.A. Moyer, ISEC 2011, Eds. F.L. Valenzuela and B.A. Moyer, Gecamin, Santiago de Chile, 2011, plenary lecture.

[58] A.M. Sastre, A. Madi, J.L. Cortina and F.J. Alguacil, J. Chem. Tech. Biotechnol. 74 (1999) 310-314.

[59] L.H. Delmau, T.J. Haverlock, E. Bazelaire, P.V. Bonnesen, M.E. Ditto and B.A. Moyer, Solvent Extr. Ion Exch. 27 (2009) 172-198.

[60] L.H. Delmau, J.F. Birdwell, J. McFarlane and B.A. Moyer, Solvent Extr. Ion Exch. 28 (2010) $19-48$.

[61] B.A. Moyer, P.V. Bonnesen, L.H. Delmau, V. Frederick, J. Sloop, N.J. Williams, F. Joseph, J. Birdwell, D.L. Lee, R.A. Leonard, S.D. Fink, T.B. Peters and M.W. Geeting. WM2011 Conference, Phoenix AZ, 2011.

[62] D.R. Raut, P.K. Mohapatra, S.A. Ansari and V.K. Manchanda, Sep. Sci. Technol. 44 (2009) 3664-3678.

[63] V.A. Babain, Simultaneously removal of radionuclides by extractant mixtures, in: Ion Exchange and Solvent Extraction, Vol. 19, Ed. B.A. Moyer, CRC Press, Boca Raton, F.L., 2010, pp. 359-380.
[64] A. Fornalczyk and M. Saternus, Metalurgija 48 (2009) 133-136.

[65] D. Martín, G. Díaz, M.A. García and F. Sánchez, J. South African Inst. Mining Metall. 102 (2002) 463-468.

[66] D. Martín, M.A. García, G. Díaz and J. Falgueras, Proc. International Solvent Extraction Conference, ISEC 1999, Barcelona, 2000, pp. 201-206.

[67] http://www.ecoren.pl/2857.xml (06.02.2013).

[68] L. Gotfryd, M. Kwarci ski, A. Chmielarz, A. Olejnik and Z. Gagat, Technology of purification of crude nickel sulphate, Institute of Non-ferrous Metals, http://www.pi.gov.pl/ppp/ chapter_95131.asp (06.02.2013).

[69] L. Gotfryd, Przem. Chem. 85 (2006) 810-813.

[70] J. Hensler, International Zinc Conference, Rancho Mirage, California, EE.UU., 2012.

[71] C. Frias, International Mining (2009) 28-29.

[72] C. Frias, G. Díaz, N. Ocaña and J.I. Lozano, Min. Eng. 15 (2002) 877-878.

[73] Dowa Group to Bring Zinc Dust Recycling Plant into Full Operation This Summer, Japan Metal Bull. (2011), available online at: http://www.japanmetalbulletin.com/?p=2859 (01.10.2012).

[74] S. Virolainen, D. Ibana and E. Paatero, Hydrometallurgy 107 (2011) 56-61.

[75] B. Mokhtari, K. Pourabdollah and N. Dallali, J. Radioanal. Nucl. Chem. 287 (2011) 921934.

[76] H. Kantekın, M.B. Kiliçaslan, F. A. Ağin, H. Alp and Ü. Ocak, J. Coordin. Chem. 63 (2010) 19211932.

[77] P.A. Tasker, C.C. Tong and A.N. Westra, Coordin. Chem. Rev. 251 (2007) 1868-1877.

[78] G. Dias Rodrigues, M.C.H. da Silva, L.H. Mendes da Silva, FJ. Paggioli, L.A. Minim and J.S. dos Reis Coimbra, Sep. Purif. Technol. 62 (2008) 687-693.

[79] L. Bulgariu and D. Bulgariu, Sep. Sci. Technol. 42 (2007) 1093-1106.

[80] V.G. Lacerda, A.B. Mageste, I.J. Boggione Santos, L.H. Mendes da Silva and M.C.H. da Silva, J. Power Sources 193 (2009) 908-913.

[81] K. Shimojo and M. Goto, Anal. Chem. 76 (2004) 5039-5044.

[82] K. Nakashima, F. Kubota, T. Maruyama and M. Goto, Ind. Eng. Chem. Res. 44 (2005) 43684372.

[83] M.P. Jensen, J.A. Dzielawa, P. Rickert and M.L. Dietz, J. Am. Chem. Soc. 124 (2002) 10664-10665

[84] A.E. Visser, R.P. Swatlowski, W.M. Reichert, S.T. Griffin and R.D. Rogers, Ind. Eng. Chem. Res. 39 (2000) 3596-3604. 
[85] X.L. Wang, J. Chen and D. Li, Proc. International Solvent Extraction Conference, ISEC 2011, Eds. F. L. Valenzuela and B. A. Moyer, Santiago de Chile, Chile, 2011, p. 218.

[86] Y. Shen, S. Wang, L. Zhu, J. Wang and W. Wu, Ind. Eng. Chem. Res. 50 (2011) 13990 13996.

[87] S. Panja, P.K. Mohapatra, S.C. Tripathi, P.M. Ghandi and P. Janardan, Sep. Purif. Technol. 96 (2012) 289-295.

[88] Z. Pan, C. Ma, H. Zhou, T. Lian, C. Lai and C. Li, Appl. Mech. Mater. 117-119 (2012) 1103-1106.

[89] A.E. Visser, R.P. Swatlowski, W.M. Reichert, R. Mayton, S. Sheff, A. Wierzbicki, J.H. Davis and R.D. Rogers, Chem. Commun. (2001) 135-136.

[90] P. Giridhar, K.A. Venkatesan, T.G. Srinivasan and P.R. Vasudewa Rao, J. Nucl. Radiochem. Sci. 5 (2004) 17-20.

[91] C.J. Bradaric, A. Downard, C. Kennedy, A.J. Robertson and Y. Zhou, Green Chem. 5 (2003) 143-152.

[92] A. Cieszyńska, M. Regel-Rosocka and M. Wiśniewski, Pol. J. Chem. Technol. 2 (2007) 99-101.

[93] A. Cieszyńska and M. Wiśniewski, Sep. Purif. Technol. 80 (2011) 385-389.

[94] A. Cieszyńska, M. Wiśniewski, Hydrometallurgy 113-114 (2012) 79-85.

[95] M. Regel-Rosocka, Sep. Purif. Technol. 66 (2009) 19-24.

[96] M. Regel-Rosocka and M. Wisniewski, Hydrometallurgy 110 (2011) 85-90.

[97] P. Rybka and M. Regel-Rosocka, Sep. Purif. Technol. 47 (2012) 1296-1302.

[98] M. Fuerhacker, T.M. Haile, D. Kogelnig, A. Stojanovic and B. Keppler, Water Sci. Technol. 65 (2012) 1765-1773.

[99] F.J. Alguacil, I. García-Díaz, F.A. López, O. Rodríguez, A. Urien and I. Padilla, Ionic liquids and smart separations technology for metal removal from wastewaters, Chapter 9 , Handbook of Ionic Liquids, Eds. J. Mun and H. Sim, Nova Science Publishers, 2011.

[100] P.R. Vasudeva Rao, K.A. Venkatesan, A. Rout, T.G. Srinivasan and K. Nagarajan, Sep. Sci. Technol. 47 (2012) 201-222.

[101]D.D. Patel and J.M. Lee, Chem. Record 12 (2012) 329-355.

[102]J. Pernak, Przem. Chem. 82 (2003) 521-524.

[103] M. Kosmulski, K. Marczewska-Boczkowska and C. Saneluta, Przem. Chem. 81 (2002) 106-110.

[104] I. Billard, A. Ouadi and C. Gaillard, Anal. Bioanal. Chem. 400 (2011) 1555-1566.

[105] A.P. Abbott, G. Frisch, J. Hartley and K.S. Ryder, Green Chem. 13 (2011) 471-481.
[106] A. Stojanovic and B. K. Keppler, Sep. Sci. Technol. 47 (2012) 189-203.

[107] K.R. Seddon, A. Stark and M.J. Torres, Pure Appl. Chem. 72 (2000) 2275-2287.

[108] L.J. Lozano, C. Godínez, A.P. de los Ríos, FJ. Hernández-Fernández, S. Sánchez-Segado and F.J. Alguacil, J. Membr. Sci. 376 (2011) 1-14.

[109]A. Rout, S. Karmakar, K.A. Venkatesan, T.G. Srinivasan and P.R. Vasudeva Rao, Sep. Purif. Technol. 81 (2011) 109-115.

[110] A. Rout, K.A. Venkatesan, T.G. Srinivasan and P.R. Vasudeva Rao. Sep. Purif. Technol. 95 (2012) 26-31

[111]A. Sengupta, P.K. Mohapatra, M. Iqbal, J. Huskens and W. Verboom, Dalton Trans. 41 (2012) 6970-6979.

[112] T.J. Bell and Y. Ikeda, Dalton Trans. 41 (2012) 4303-4305.

[113] A. Pérez de los Ríos, F.J. Hernández-Fernández, S. Sánchez-Segado, L.J. Lozano, J.I. Moreno and C. Godinez, Chem. Eng. Transactions 21 (2010) 625-630.

[114] A. Pérez de los Ríos, FJ. Hernández-Fernández, FJ. Alguacil, L.J. Lozano, A. Ginestá, I. García-Díaz, S. Sánchez-Segado, F.A. López and C. Godínez, Sep. Purif. Technol. 97 (2012) 150-157.

[115]M.T. Coll, A. Fortuny, C.S. Kedari and A.M. Sastre, Hydrometallurgy 125-126 (2012) 24-28.

[116] L. Kejun, W.T. Yen, A. Shibayama, T. Miyazaki and T. Fujita, Hydrometallurgy 73 (2004) 41-53.

[117] T. Sato, T. Takayanagi and K. Sato, Solvent Extr. Res. Dev., Japan 17 (2010) 95-110.

[118] B. Wionczyk, Solvent Extr. Ion Exch. 27 (2009) 423-446.

[119] P. Giridhar, K.A. Venkatesan, T.G. Srinivasan and P.R. Vasudeva Rao, Hydrometallurgy 81 (2006) 30-39.

[120]M. Srncik, D. Kogelnig, A. Stojanovic, W. Körner, R. Krachler and G. Wallner, Appl. Radiat. Isotopes 67 (2009) 2146-2149.

[121]D. Kogelnig, A. Stojanovic, M. Galanski, M. Groessl, F. Jirsa, R. Krachler and B.K. Keppler, Tetrahedron Lett. 49 (2008) 2782-2785.

[122] Alok Rout, K.A. Venkatesan, T.G. Srinivasan and P.R. Vasudeva Rao, Sep. Purif. Technol. 95 (2012) 26-31.

[123] H. Yang, W. Wang, H. Cui, D. Zhang, Y. Liua and J. Chen, J. Chem. Technol. Biotechnol. 87 (2012) 198-205.

[124] A. Stojanovic, D. Kogelnig, L. Fischer, S. Hann, M. Galanski, M. Groessl, R. Krachler and B.K. Keppler, Aust. J. Chem. 63 (2010) 511 524.

[125] B. Galán, D. Castañeda and I. Ortiz, Water Res. 39 (2005) 4317-4324. 
[126] F.J. Alguacil, M. Alonso, F.A. López, A. LópezDelgado, I. Padilla and H. Tayibi, Chem. Eng. J. 157 (2010) 366-372.

[127]R.E. Del Sesto, C. Corely, A. Robertson and J.S. Wilkes, J. Organometal. Chem. 690 (2005) 2536-2542.

[128] A.N. Turanov, V.K. Karndashev, V.E. Baulin, Russ. J. Inorg. Chem. 53 (2008) 970-975.

[129] D. Kogelnig, A. Stojanovic, F. Jirsa, W. Körner, R. Krachler and B.K. Keppler, Sep. Purif. Technol. 72 (2010) 56-60.

[130] V. Gallardo, R. Navarro, I. Saucedo, M. Ávila and E. Guibal, Sep. Sci. Technol. 43 (2008) 2434-2459.

[131]E. Guibal, K. Gavilan Campos, P. Bunio, T. Vincent and A. Trochimczuk, Sep. Sci. Technol. 43 (2008) 2406-2433.

[132]K. Campos, T. Vincent, P. Bunio, A.
Trochimczuk and E. Guibal, Solvent Extr. Ion Exch. 26 (2008) 570-601.

[133] S. Katsuta, Y. Yoshimoto, M. Okai, Y. Takeda and K. Bessho, Ind. Eng. Chem. Res. 50 (2011) 12735-12740.

[134]J. M. Lee, Fluid Phase Equilibria 319 (2012) 30-36.

[135] M.T. Coll, I. García-Díaz, A. Fortuny, F.A. López, A.M. Sastre and FJ. Alguacil, Proc. International Solvent Extraction Conference, ISEC 2011, Eds. F.L. Valenzuela and B.A. Moyer, Gecamin, Santiago de Chile, Chile, 2011, p. 220.

[136] D. de Agreda, I. García-Díaz, F.A. López and F.J. Alguacil, Rev. Metal. 47 (2011) 146-168.

[137]I. Padilla, I. García-Díaz, A. Urien, O. Rodríguez, F. López and F.J. Alguacil, Desalin. Water Treat. 40 (2012) 282-297. 